\title{
Music in Concentration Camps 1933-1945
}

\section{GUIDO FACKLER}

Translated from the German by Peter Logan (Würzburg)

It would be wrong to reduce the "Music of the Shoah" (Holocaust/churbn) to the Yiddish songs from the ghetto camps of Eastern Europe or to the multiple activities in the realm of classical or Jewish music found in the ghetto camp at Theresienstadt (Terezín), which of course enjoyed a special status as a model camp. It would be equally wrong to restrict our view of music in concentration camps to the "Moorsoldatenlied" ("The Peat Bog Soldiers"), the "Buchenwald Song," the "Dachau Song," or the so-called "Girls' Orchestra in Auschwitz," described by Fania Fénelon - also the subject of the Hollywood film entitled "Playing for Time". ${ }^{1}$ Instead of this, I wish to address the topic of musical activities in general in the concentration camps. ${ }^{2}$ Thus this chapter is about those camps that the Nazi regime started to erect just a few weeks after Hitler's assumption of power; these camps formed the seed from which the entire system of Nazi camps grew, and which eventually consisted of over 10,000 camps of various kinds. ${ }^{3}$

In fact music was an integral part of camp life in almost all the Nazi-run camps. The questions covered by my research include: how was it possible to play music in these camps? What musical forms developed there? What, under these circumstances was the function, the effect and the significance of music for both the suffering inmates and the guards who inflicted the suffering? And how was the extent of musical activities affected by the development of the concentration camp system? My research is based on extensive archive work, the study of memoirs and literature, and interviews with witnesses. In the first part of this essay I describe the various forms of music performed at the behest of the SS in the camps. In the second part I analyze the very different question of the musical activities initiated by the inmates themselves.

\section{Music on Command}

Almost every camp inmate was inescapably confronted in one way or another with music in the course of his or her camp imprisonment. This took place mainly within the officially prescribed framework of daily life in the camps: singing was required and there were camp orchestras; but music was also played over loudspeakers. Besides these occasions, camp inmates were forced to perform music for the SS “after hours," as it were.

1 See Fania Fénelon, Playing for Time: The Musicians of Auschwitz, transl. from the French by Judith Landry (New York, 1977). Arthur Miller wrote the screenplay for the film Playing for Time (Columbia Broadcasting System/ CBS 1980) with Vanessa Redgrave as Alma Rosé, directed by Daniel Monn.

2 See Guido Fackler, "Des Lagers Stimme”- Musik im KZ. Alltag und Häftlingskultur in den Konzentrationslagern 1933 bis 1936. Mit einer Darstellung der weiteren Entwicklung bis 1945 und einer Biblio-/ Mediographie, vol. 11 of DIZ-Schriften (Bremen, 2000).

3 See Martin Weinmann, ed., Das nationalsozialistische Lagersystem (CCP). Mit Beiträgen von Anne Kaiser und Ursula Krause-Schmitt (Frankfurt a. M., 1990); Gudrun Schwarz: Die nationalsozialistischen Lager, 2nd ed. (Frankfurt a. M., 1996). 


\section{Music and Politics Winter 2007}

\section{Singing on Command}

Once the camp system had been developed, the most common form of command music in the concentration camps was singing on command. ${ }^{4}$ The inmates received the order to strike up a song from a sentry, for example, or from a prisoner functionary (the latter were prisoners to whom the SS had delegated such special organizational and administrative tasks as leading a work detail or supervising a block: for example, a Kapo). This form of collective music derives from military tradition, where even today singing is used to develop discipline, encourage marching rhythm, or to symbolize the acquisition of such soldierly virtues as "proper order". The practice was employed in concentration camps, however, with the additional purpose of exercising mental and physical force. The guards used singing on command to intimidate insecure prisoners: it frightened, humiliated, and degraded them. After a long day of hard manual work, being forced to sing meant an enormous physical effort for the weakened prisoners.

In fact, under these extreme conditions, being forced to sing could be life-threatening. Prisoners who did not immediately obey the order, "In step ... March! Sing!," out the order, "Sing, a Song!" to the complete satisfaction of the SS provided an occasion for random beatings, as reported by Eberhard Schmidt from the Sachsenhausen concentration camp: "Anyone who did not know the song was beaten. Anyone who sang too softly was beaten. Anyone who sang too loud was beaten. The SS men lashed out wildly"? Karl Röder, who had been a prisoner in Dachau and Flossenbürg, wrote that singing songs on command was part of the daily routine of camp life: "We sang in small groups, or one block would sing, or several thousand prisoners all at once. In the latter case, one of us had to conduct because otherwise it would not have been possible to keep time. Keeping time was very important: it had to be crisp, military, and above all loud. After several hours' singing we were often unable to produce another note". ${ }^{8}$

Command singing took place on several occasions; while marching, while doing exercises, during roll-call, and on the way to or from work. Frequently, singing was compulsory even during forced labor. It was by no means unusual for singing to provide the macabre background music for punishments, which were stage-managed as a deterrent, or even as a means of sadistic humiliation and torture. Joseph Drexel in the Mauthausen concentration camp for instance, was forced to give a rendering of the church hymn "O Haupt voll Blut und Wunden" (“Jesus' blood and wounds") while being flogged to the point of unconsciousness. Punishment beatings over the notorious flogging horse (the "Bock") were performed accompanied by singing, and the same is true of executions.

4 See Guido Fackler, "Des Lagers Stimme”- Musik im KZ, 130-151 (1933-1936), 157-161 (camp choirs), 329-340 (1936-1945); Guido Fackler, "Lied und Gesang im KZ," Lied und populäre Kultur/ Song and Popular Culture. Fahrbuch des deutschen Volksliedsarchivs 46 (2001), 139-196.

5 Zenon Rozanski, Mützen ab ... Eine Reportage aus der Strafkompanie des KZ Auschwitz (Oldenburg, 1991 ), 26.

6 Richard Glazar, Die Falle mit dem grünen Zaun. Überleben in Treblinka, vol. 4 of Lebensbilder. Füdische Erinnerungen und Zeugnisse (Frankfurt a. M., 1992), 41.

7 Eberhard Schmidt, Ein Lied - ein Atemzug. Erinnerungen und Dokumente. Gesprächspartner und Herausgeber Manfred Machlitt (Berlin, 1987), 130.

8 Karl Röder, Nachtwache. 10 Jahre KZ Dachau und Flossenbürg, vol. 8 of Dokumente zu Alltag, Politik und Zeitgeschichte (Vienna, Cologne, and Graz, 1985), 113.

9 See Wilhelm R. Beyer, ed., Rückkehr unerwünscht. Joseph Drexels "Reise nach Mauthausen" und der Widerstandskreis Ernst Niekisch (München, 1980), 110-112. 


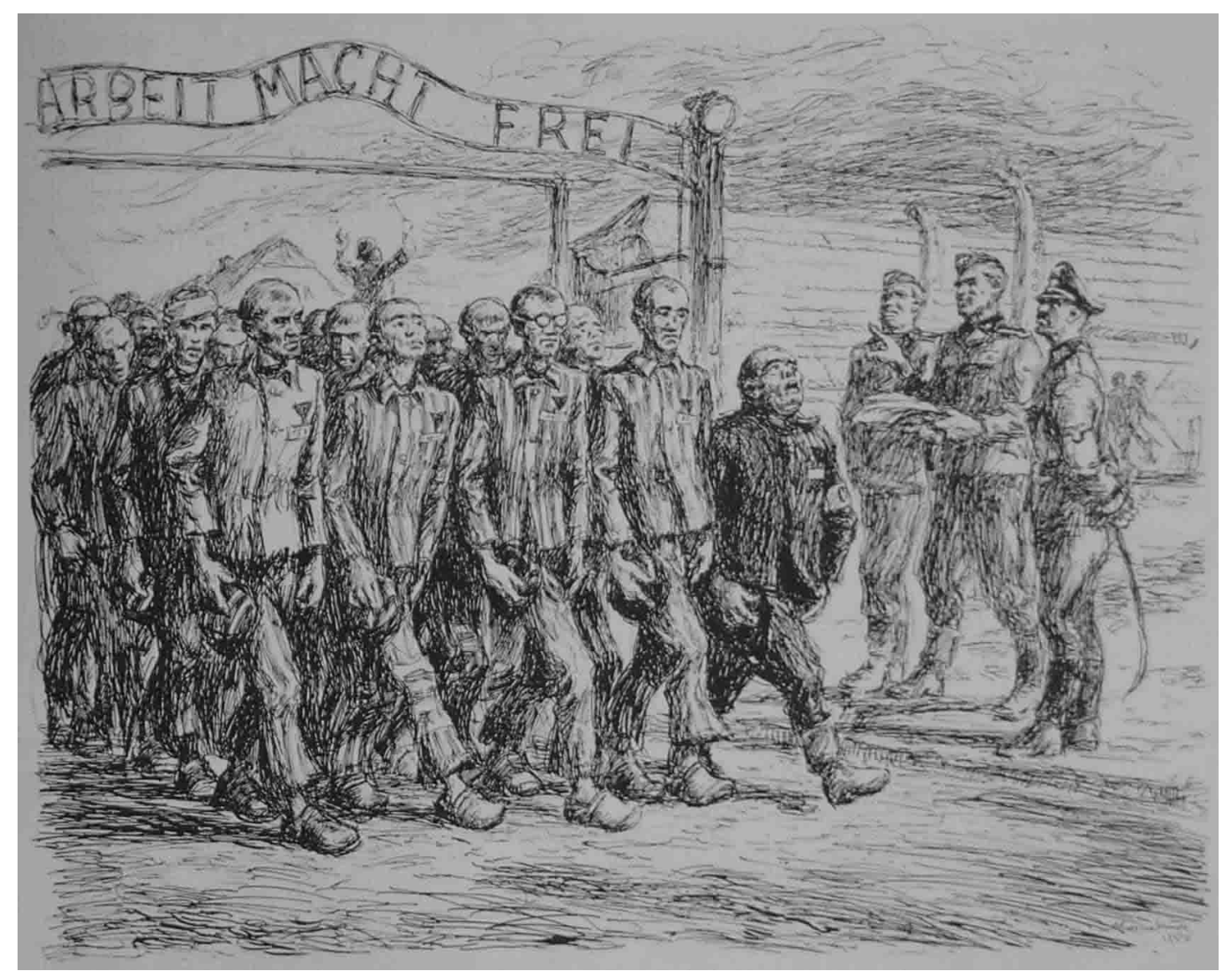

Figure 1. This pen-and-ink drawing under the title "Wymarsz komand do praxy" ("Marching to work"), from the cycle "Day of the prisoner" (1950), was made by Mieczysław Koscielniak, a former prisoner, in 1950. It shows a work detail leaving Auschwitz: in the background a prisoner can be seen conducting the camp orchestra (published in M. Koscielniak: Bilder von Auschwitz, 2d ed. (Frankfurt a. M., 1986, n.p.)

The demoralizing effect of being forced to sing resulted not just from the situations in which the prisoners were forced to sing, but also from the deliberate choice of certain songs. While the guards and officials did not usually prescribe any particular song, the prisoners generally chose pieces which were not calculated to unnecessarily provoke the guards. German folk songs with banal, countrified or naive texts, were particularly popular with the SS and were repeated to the point of stupefaction. These songs, of course, formed a harsh contrast with the hopeless situation of the prisoners. According to Eugen Kogon, who was imprisoned in the Buchenwald camp, a degree of "stoicism and callousness" ${ }^{10}$ was necessary in order to endure such songs as "Hoch auf dem gelben Wagen" ("Up there on the yellow wagon") or "Auf den Bergen so hoch da droben steht ein Schloß" ("High on the mountains yonder stands a castle"), ${ }^{11}$ or the sentimental ballad "Hüttlein am

10 Eugen Kogon, Der SS-Staat: Das System der deutschen Konzentrationslager, 18th ed. (München, 1988), 105.

11 Karl Röder, Nachtwache. 10 Jahre KZ Dachau und Flossenbürg, 114. 
Waldesrand" ("Little hut on the edge of the forest") ${ }^{12}$ while faced with the daily terror of life in the camps. When the guards ordered the prisoners to sing such Nazi songs as the "Horst-Wessel-Lied" ("Horst-Wessel-Song"), or military or patriotic songs, this confronted the prisoners with the contrast between the National Socialist view of life and their own hopeless situation. Alternatively, the prisoners might be ordered to sing songs with double-meanings, or obscene or salacious texts, offending the prisoners' sense of shame. Certain groups of prisoners were deliberately humiliated by being forced to sing songs of particular significance to that group; and the guards showed "an astonishing awareness of how to outrage people by breaking taboos and abusing symbols". ${ }^{13}$ Communists and Social Democrats, for instance, were forced to sing songs from the workers' movement, while the faithful were forced to sing their religious songs.

The guards forced prisoners to sing not just well-known songs, but also songs which originated in the camps. These so-called concentration camp songs were either newly composed or else variations on existing songs. Thus, "Wir sind die Sänger von Finsterwald" ("We are the Darkwood Singers") became "Wir sind die Sänger von Buchenwald" ("We are the Buchenwald - Beechwood - Singers"). ${ }^{14}$ Other camp songs were specially commissioned by the SS, including the anti-Semitic "Judenlied" ("Jews' Song"), which was composed by a prisoner in Buchenwald who had been assessed as 'asocial.' The song begins: 'Jahrhundert' haben wir das Volk betrogen, / kein Schwindel war uns je zu groß und stark, / wir haben geschoben nur, gelogen und betrogen, / sei’s mit der Krone oder mit der Mark" ("For hundreds of years we cheated the people, / no swindle was too outrageous / we wangled, we lied, we cheated, we narked / whatever the currency, the crown or the mark"). ${ }^{15}$

Besides these songs, many concentration camps had their own special anthem which served as a sort of official signature tune for the camp. The model for all these concentration camp anthems (KZ-Hymnen) was composed in the summer of 1933 in the Börgermoor concentration camp near Papenburg. This is the "Börgermoorlied" ("Song of Börgermoor"), but it is better know under the title "Moorsoldatenlied" (also "Die Moorsoldaten" or "Lied der Moorsoldaten," English: "The Peat Bog Soldiers" or "The Peat Bog Soldiers' Song”). ${ }^{16}$ This song was not the brainchild of the SS: in fact it was repeatedly prohibited. Nevertheless it spread throughout the camp system as prisoners were transferred to other camps. In this way it became the most popular of all concentration camp songs, symbolizing for the inmates both protest and determined endurance.

12 Ernst Wiechert, Der Totenwald (Berlin, 1977), 112. Quoted from Sonja Seidel, Kultur und Kunst im antifaschistischen Widerstandskampf im Konzentrationlager Buchenwald, vol. 18 of Buchenwaldheft (Weimar-Buchenwald, 1983 ), 11.

13 Christoph Daxelmüller, "Kultur gegen Gewalt. Das Beispiel Konzentrationslager," in Rolf Wilhelm Brednich and Walter Hartinger, eds., Gewalt in der Kultur. Vorträge des 29. Deutschen Volkskundekongresses Passau 1993, vol. 9 of Passauer Studien zur Volkskunde, 2 vols. (Passau, 1994), vol. 1, 223-269, quote on 258.

14 See Wilhelm Tichauer, "Lieder beim Appell zu singen" (archive of the Gedenkstätte Buchenwald/ Buchenwald Memorial in Weimar, Germany, BwA 9-98-8), 1.

15 Eugen Kogon, Der SS-Staat, 308.

16 See Wolfgang Langhoff, Die Moorsoldaten (Cologne, 1988), 165-186; Lieder aus den faschistischen Konzentrationslagern. Collected by Inge Lammel und Günter Hofmeyer, vol. 7 of Das Lied - Im Kampf geboren (Leipzig, 1962), 14-18 and illustrations; Gisela Probst-Effah, "Das Moorsoldatenlied," Fahrbuch für Volksliedforschung 40 (1995), 75-83; Guido Fackler, "Des Lagers Stimme" - Musik im KZ, 245-265. See also the double-cd with different recordings of "The Peat Bog Soldiers” from 1937 until 1999 and booklet with 64 pages: Fietje Ausländer, Susanne Brandt and Guido Fackler, Das Lied der Moorsoldaten 1933 bis 2000. Bearbeitungen - Nutzungen - Nachwirkungen, ed. Dokumentations- und Informationszentrum (DIZ) Emslandlager, Papenburg, in cooperation with Stiftung Deutsches Rundfunkarchiv, Frankfurt a.M. and Potsdam-Babelsberg (Papenburg, 2002, online URL: http://www.diz-emslandlager.de/cd02.htm ). 


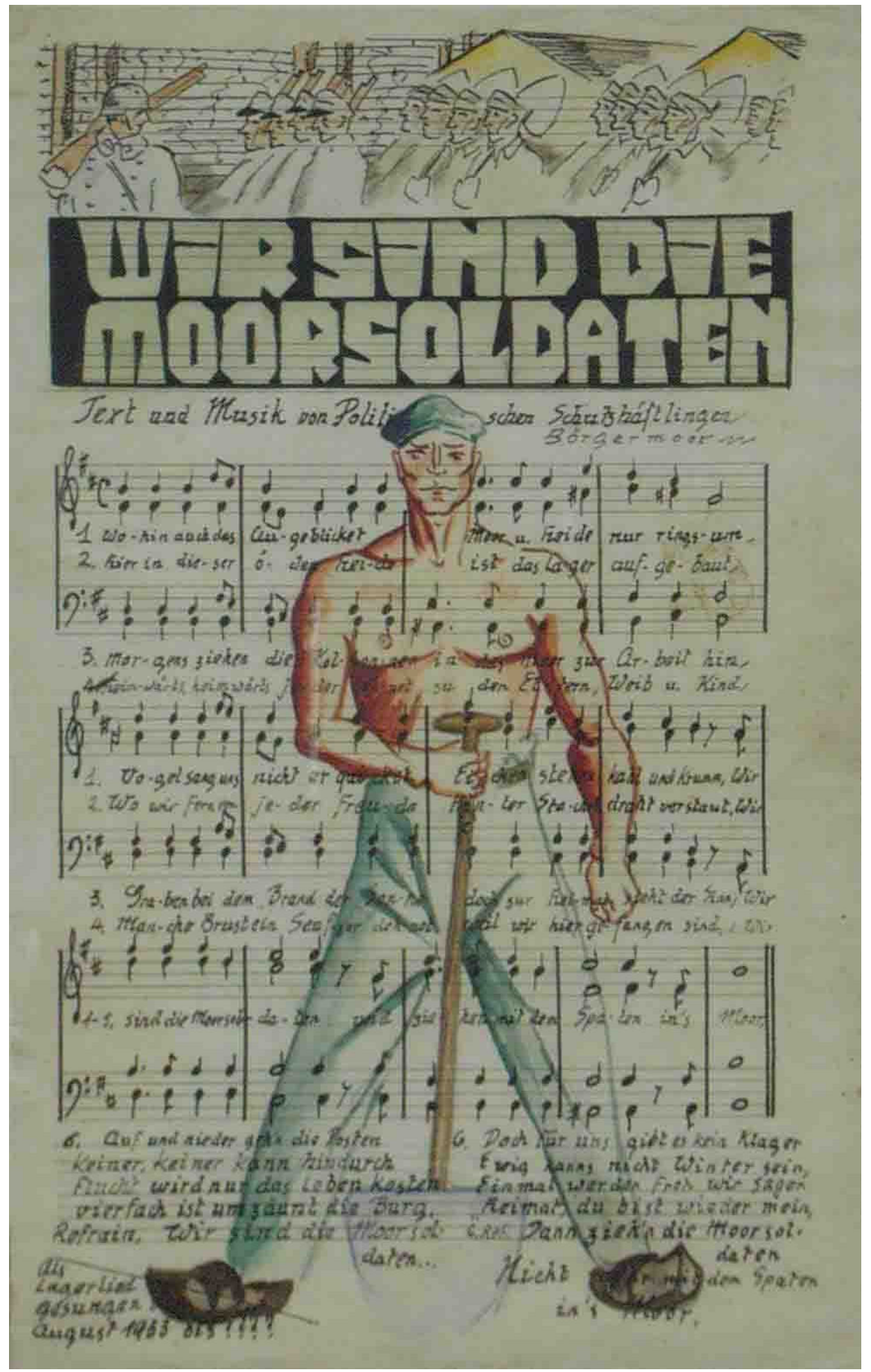

Figure 2. A copy of the "The Peat Bog Soldiers" made by Hanns Kralik in the KZ Börgermoor 1933. After his release Günter Daus brought this copy outside the camp. Archive of Dokumentations- und Informationszentrum Emslandlager (Documentation and Information Center Emslandlager) in Papenburg, Germany, estate Günter Daus. 
The text of another concentration camp anthem, the "Treblinkalied" ("Treblinka Song"), ${ }^{17}$ is probably the work of a member of the SS, Kurt Hubert Franz, while the tune is that of the "Buchenwaldlied" ("Buchenwald Song", lyrics: Fritz Löhner-Beda, music: Hermann Leopoldi), ${ }^{18}$ written in December 1938 on order of the camp commander. The commander in the KZ Sachsenhausen also ordered a camp anthem to be written, and this resulted in winter 1936/37 in the "Sachsenhausenlied" ("Sachsenhausen Song”). ${ }^{19}$

\section{Music Relayed from Radio or Gramophone}

In some camps prescribed music was forced on the inmates in a second way: music from radio or gramophones was played over permanently installed loudspeakers. ${ }^{20}$ In 1933 this system was used in particular in the Dachau camp to re-educate the inmates - who were political opponents of the regime - using propaganda speeches and so-called national music, for example, from the German composer and antisemite Richard Wagner. ${ }^{21}$ In later years, however, this system was used predominantly to demoralize the prisoners. The victory announcements from the German radio station were designed to break the inner resistance of the inmates. Female prisoners in the Ravensbrück concentration camp, for instance, were informed of the failed attempt on Hitler's life by a radio announcement, followed by martial march-music. ${ }^{22}$ The loudspeaker system, or tannoy, was mainly used, however, to issue internal camp announcements and instructions from those in charge. In Buchenwald, the SS men on guard sometimes on a whim allowed the prisoners to listen

17 Different versions about the songwriter and the composer are existing. See Richard Glazar, Die Falle mit dem grünen Zaun. Überleben in Treblinka, 118-119; Alexander Donat, ed., The Death Camp Treblinka. A Documentary (New York, 1979), 306; Samuel Willenberg, Revolt in Treblinka (Warszaw, 1984), 133.

18 See Ilse Schulz, "Kunst und Literatur als Waffe im Kampf gegen den Faschismus im Konzentrationslager Buchenwald" (unpublished Staatsexamensarbeit at the University of Leipzig, 1957), 25-29; Lieder aus den faschistischen Konzentrationslagern, 74-77; Wolfgang Schneider, Kunst hinter Stacheldraht. Ein Beitrag zur Geschichte des antifaschistischen Widerstandskampfes, ed. Nationale Mahn- und Gedenkstätte Buchenwald (Weimar, 1973), 103-107; Sonja Seidel, Kultur und Kunst im antifaschistischen Widerstandskampf im Konzentrationslager Buchenwald, 12-15; Sonja Staar, Kunst, Widerstand und Lagerkultur. Eine Dokumentation, vol. 27 of Buchenwaldheft (Weimar-Buchenwald, 1987), 14-18; Karl Mellacher, Das Lied im österreichischen Widerstand. Funktionsanalyse eines nichtkommerziellen literarischen Systems, vol. 44 of Materialien zur Arbeiterbewegung (Wien, 1986), 112-115; Eugen Kogon, Der SS-Staat, 106-108; Milan Kuna, Musik an der Grenze des Lebens. Musikerinnen und Musiker aus böhmischen Ländern in nationalsozialistischen Konzentrationslagern und Gefängnissen, transl. Eliska Nováková (Frankfurt a. M., 1993), 63-66; Robert Dachs, Sag beim Abschied ... (Wien, 1994); Guido Fackler, "Des Lagers Stimme“ - Musik im KZ, 338-339; Günther Schwarberg, Dein ist mein ganzes Herz. Die Geschichte von Fritz LöhnerBeda, der die schönsten Lieder der Welt schrieb, und warum Hitler ihn ermorden ließ (Göttingen, 2000); Barbara Denscher and Helmut Peschina, Kein Land des Lächelns - Fritz Löhner-Beda 1883-1942 (Wien, Salzburg, Frankfurt a.M., 2003).

19 See Lieder aus den faschistischen Konzentrationslagern, 51-54; Harry Naujoks, Mein Leben im KZ Sachsenhausen $1936-1942$. Erinnerungen des ehemaligen Lagerältesten. Bearbeitet von Ursel Hochmuth, ed. Martha Naujoks und SachsenhausenKomitee für die BRD (Berlin, 1989), 51-52; ... denn in uns zieht die Hoffnung mit. Lieder, gesungen im Konzentrationslager Sachsenhausen. Wolfgang Szepansky Häftlings-Nr. 33.527. Emil Ackermann Häftlings-Nr. 775, ed. Sachsenhausenkomitee Westberlin (Berlin, n.d.), 4-5; Katja Klein, Kazett-Lyrik. Untersuchungen zu Gedichten und Liedern aus dem Konzentrationslager Sachsenhausen (Würzburg, 1995), especially 13- 15; Guido Fackler, "Des Lagers Stimme” - Musik im KZ, 336-338; Juliane Kunze, "Gesang als Überlebensstrategie im Konzentrationslager Sachsenhausen" (unpublished Magisterarbeit at the University of Berlin, 2001), especially 57-58; Guido Fackler, “'Machts ein eigenes Lagerlied ...' Liedwettbewerbe im KZ”, Dietrich Helms / Thomas Phleps (eds.): Keiner wird gewinnen. Populäre Musik im Wettbewerb, vol. 33 of Beiträge zur Popularmusikforschung (Bielefeld, 2005), 57-81.

20 See Guido Fackler, “Des Lagers Stimme“ - Musik im KZ, 151-157, 176-180 (1933-1936), 356-361(1936-1945).

21 See Guido Fackler, “ ‘... den Gefangenen die nationalen Flötentöne beibringen.' Musikbeschallung im frühen KZ Dachau," Zeitenweise. Geschichtsmagazin für München, no. 2 (1998), 20-22. Expanded and revised reprint mr-Mitteilungen (ed. musica reanimata e.V., Berlin), no. 28 (1998), 8-16.

22 See Anja Lundholm, Das Höllentor. Bericht einer Überlebenden (Reinbek, 1988), 37. Generally to music in Ravensbrück see Gabriele Knapp, Frauenstimmen. Musikerinnen erinnern an Ravensbrück (Berlin, 2003). 
in over the loudspeakers to other music broadcasts, for instance to broadcasts of philharmonic concerts on German radio station (Deutschlandsender), or else they might put on a recording of Zarah Leander, for example. ${ }^{23}$

There are only occasional cases recorded, on the other hand, of music being played over mobile loudspeaker systems. Loudspeakers mounted on special vehicles were in use in Majdanek, an extermination camp, and from them poured unremitting dance music - fox-trot - during executions, the purpose being to confuse the victims of the genocide, to quieten them, and also to drown out the screams of the dying. ${ }^{24}$ Marching music was switched on in the Sachsenhausen concentration camp when people were being shot. Former SS-Medical Director Heinz Baumkötter admitted under interrogation that the purpose was "to ensure that the next prisoner did not hear the shot that killed his predecessor" ${ }^{25}$ When deeds like these were perpetrated, music - usually accompanied by alcohol - was deliberately used to lower inhibitions and drown out any scruples or doubts the murderers might have had about their actions.

\section{The Official Camp Orchestras}

The most remarkable feature of command music was the existence of official camp orchestras (or camp ensembles), the Lagerkapellen. Amateur and professional musicians among the prisoners formed these ensembles, which were either ordered by the camp administration or tolerated by the officials. The musicians played, first and foremost, as directed by the SS. The first of these ensembles came into existence as early as 1933 and they were present in the early concentration camps such as Oranienburg, Sonnenburg and probably also in Hohnstein; ${ }^{26}$ another ensemble played at the Duerrgoy concentration camp near Breslau. ${ }^{27}$

In the Esterwegen concentration camp, where there also was a camp choir, the camp orchestra was established in 1935 by the camp commander - a music lover. ${ }^{28}$ Willi Stein directed this sixteenmember musical group, which rehearsed in hut number 12. The music was in the tradition of a medium-sized drawing-room orchestra, playing popular classics and a higher form of light music known as Salonmusik. Among the main tasks of the ensemble was to perform concerts in the camp square for fellow-prisoners, although guards were also part of the audience. However, while the apparent or ostensible purpose of these concerts was to entertain and edify the prisoners, they were, in fact, designed for a different purpose. When a delegation from the International Red Cross

23 See Eugen Kogon, Der SS-Staat, 154; Jorge Semprún, Die große Reise (Berlin, 1966), 40-41, 290; Jorge Semprún, Was für ein schöner Sonntag!, transl. from French by Johann Piron, 6th ed. (Frankfurt a. M., 1984), 53-54.

24 See Zacheusz Pawlak, "Ich habe überlebt ...". Ein Häftling berichtet über Majdanek, foreword by Gerhard Mauz (Hamburg, 1979), 137, 140; Aleksander Kulisiewicz, "Dalsze przyczynki do zagadnień psychopatologii muzyki i pieśni w obozach hitlerowskich" (some remarks to the psychopathy of music and songs in nazi camps), Przeglad Lekarski 32, no. 1 (1975), 33-40, here 40; Czesław Pilichowski, Es gibt keine Verjährung (Warsaw, 1980), 137, 139; Harald Focke and Uwe Reimer, Alltag unterm Hakenkreuz. Vol. 2: Alltag der Entrechteten. Wie die Nazis mit ihren Gegnern umgingen (Reinbek, 1983), 186; Raul Hilberg, Die Vernichtung der europäischen Fuden. Die Gesamtgeschichte des Holocaust, 3 vols. (Frankfurt a. M., 1990), 559; Günter Schwarberg, Der Fuwelier von Majdanek (Göttingen, 1991), 81.

25 Quoted from SS im Einsatz. Eine Dokumentation über die Verbrechen der SS, 8th ed. (Berlin, 1967), 300.

26 See Guido Fackler, "Des Lagers Stimme“- Musik im KZ, 161-163.

27 Ibid., 126-127. See also Paul Löbe, Der Weg war lang. Lebenserinnerungen von Paul Löbe. Ehemals Präsident des Deutschen Reichstages und Alterspräsident des 1. Deutschen Bundestages (Berlin, 1954), 223-224.

28 See Guido Fackler, "Des Lagers Stimme"- Musik im KZ, 163-169, for the camp choir see 159-161. See also Valentin Schwan, Bis auf weiteres (Darmstadt, 1961), especially 599-609, 637-646. 
visited the camp in October 1935, the commander used the ensemble for propaganda: musical performances were used to make things seem better than they were; and the outside world was deceived as to the real purpose of the camps.

From 1936 onwards, the entire concentration camp system was re-organized: the early camps, with the exception of Dachau, were dismantled and replaced by newer, bigger ones. From that point until the outbreak of war, prisoner ensembles existed in three camps: Sachsenhausen (this orchestra was the successor of that from the Esterwegen concentration camp), Buchenwald, and Dachau. ${ }^{29}$ As the concentration camp system expanded, and as a satellite system of subsidiary camps was put in place after 1942, many large camps saw the setting up of official camp ensembles: most of the main camps, some larger subsidiary or sub camps, and almost all extermination camps. In some cases there were several ensembles operating simultaneously, for instance in the complex of camps known as Auschwitz. ${ }^{30}$

There were various motives for setting up camp orchestras. On the one hand, these musical groups could be used in various ways in the daily life of the camp. On the other hand, ambitious camp commanders emulated what they had seen in other camps, and of course the prestige and cultural status of having their “own” prisoners' orchestra was also an incentive. From 1942 on, more and more concentration camp inmates were put to work in the war industry; and on 15 May 1943 the SS granted a "bonus-system" ("Prämiensystem"), to increase the work rate. The so-called "privileged" prisoners, especially prisoner functionaries, "prominents," and those prisoner groups at the top of the hierarchy profited. And so the differences within the prisoner society grew, while no basic improvement in camp conditions resulted for the majority of the inmates. Although these concessions did not directly concern cultural or artistic activities, it was easier to organize them; ${ }^{31}$ as a result, many camp ensembles were formed officially.

The lineup in the camp orchestras varied from a temporary trio in Treblinka with mandolin, violin and a wind instrument, to the eighty-strong long-term symphony orchestra in the main camp at Auschwitz. ${ }^{32}$ In most cases, however, they were medium-sized groups consisting predominantly of wind and string instruments. Except in the case of the women's camp of Birkenau, which had the only female orchestra, at times conducted by Alma Rosé, ${ }^{33}$ all these groups consisted exclusively of

29 See Guido Fackler, "Des Lagers Stimme“ - Musik im KZ, 340-356; Aleksander Kulisiewicz, "Orkiestry w obozach koncentracyjnych" (the orchestras in concentration camps), Życie Muzyczne (Warsaw), no. 4 (1977), 3-8.

30 See Szymon Laks, Music of Another World (Evanston, Illinois: Northwestern UP, 1989); Ignacy Szczepański, Häftlingskapelle (Warsaw, 1990); Thomas Kallenborn, "Die Orchester in Auschwitz während des Nationalsozialismus" (unpublished Magisterarbeit at the University of Saarbrücken, n.d. [1992/93]); Hans-Ludger Kreuzheck, "Kapellen der Hölle. Die offiziellen Lagerkapellen in Auschwitz und anderen Konzentrationslagern," Informationsblatt (ed. Musik von unten e.V., Hamburg), 8/9 (1995/96), part 1: no. 17 (1995), 33-44, part 2: no. 18 (1995/96), 28-43, part 3: no. 19 (1996), 323; Guido Fackler, “This Music is Infernal ...': Music in Auschwitz," online URL: http://tle.northwestern.edu/essays/essay_Fackler_pdf_g.html; Guido Fackler, “'We all feel this Music is infernal ...': Music on Command in Auschwitz," in The Last Expression. Art and Auschwitz, ed. David Mickenberg, Corinne Granoff and Peter Hayes (Chicago, 2003), 114-125. See also note 1 and 33.

31 See Karin Orth, Das System der nationalsozialistischen Konzentrationslager. Eine politische Organisationsgeschichte (Hamburg, 1999), 192-198.

32 On Auschwitz see note 30. For Treblinka see Annkatrin Dahm, "Musik in den nationalsozialistischen Vernichtungslagern in Polen" (unpublished Magisterarbeit at the University of Freiburg i.Br., 1994), 33-34. Besides this orchestra, there were other camp ensembles in Treblinka later, for example a 10-member-band conducted by Arthur Gold. See Richard Glazar, Die Falle mit dem grünen Zaun. Überleben in Treblinka, 118-119.

33 See Gabriele Knapp, Das Frauenorchester in Auschwitz. Musikalische Zwangsarbeit und ihre Bewältigung, vol. 2 of Musik im "Dritten Reich" und im Exil (Hamburg, 1996). For Alma Rosé see Gabriele Knapp, "Alma Rosé: Geigerin, Dirigentin," in 
men. The repertoire was varied, depending on the occasion and generally included marching music, songs, camp anthems, light music, dance music, popular songs, film music, operetta melodies, but also classical music and excerpts from operas. There were also new arrangements and original compositions. Some music sheets from the Art Collection of the Auschwitz-Birkenau State Museum will show the scope of the repertoire performed by the orchestra of the main camp of Auschwitz, which played Beethoven's "Fifth Symphony", the popular song "Die schönste Zeit des Lebens" ("The Best Time of Life"), or the "Arbeitslagermarsch" ("The Labor Camp March"), composed in Auschwitz by Mieczysław Krzyński und Henryk Król. ${ }^{34}$

Compared to the singing done on command, the camp orchestras offered a far broader spectrum of music, but they also demanded a much greater organizational effort. Sheet music, instruments, and other equipment had to be procured - in most cases this all came from inmates or was purchased with their money. The position of ensemble members was "privileged" compared to that of other prisoners, enabling many of them to survive. Although they enjoyed certain "privileges," ensemble members were still subject to the unpredictable whims of SS-men. Like all other prisoners they were forced to work, although assigned to the less laborious work details; other prisoners were frequently jealous of their "privileges", and there was fierce competition for the favor of Kapos and SS-men.

The purposes of the camp orchestras depended largely on the quality of the musicians involved, and also on the interest of the camp administrations, as well as the type of camp. Like compulsory singing, the camp ensembles were also used to provide the rhythm which helped to keep the marching columns of prisoners in step as they left the camp, or as they returned to the camp.

The camp orchestras also provided background music for punishments and executions. On 30 July, 1942, in the Mauthausen concentration camp, Hans Bonarewitz was recaptured after an escape attempt. ${ }^{35} \mathrm{He}$ was preceded by the camp ensemble as he was led to his execution past his comrades who stood in ranks. These orchestras also played on ceremonial occasions. They held performances on Hitler's birthday, for instance, and other Nazi public holidays. An ambitious camp commander with cultural pretensions might also use the orchestras to advertise the "orderly" conditions within "his" camp when it was being inspected, or when visitors were shown around. The ensembles also gave concerts for the entertainment of the SS, or with their permission for the inmates, generally in connection with the "privileges" already mentioned. In the summer months open-air concerts were frequently held for the prisoners in some camps, including the main camp in

Arbeitsgruppe Exilmusik, ed., Lebenswege von verfolgten Musikerinnen im Dritten Reich und im Exil (Hamburg, 2000), 199225; Richard Newman with Karen Kirtley, Alma Rosé. Vienna to Auschwitz (Portland, Oregon, 2000). See also the cd and 48-page booklet: Wolfgang Wendel, Meister des Bogens. Váša Príhoda-Alma Rosé-Arnold Rosé. Dokumentation eines Fahrhundert-Dramas (Karlsruhe, 1999, POL-1007-2, e-mail: wendel.podium@t-online.de ). For further literature, reports and documentary films see note 1 and Guido Fackler, "Des Lagers Stimme"- Musik im KZ, 503-504, 511, 545-550, 563.

34 See Art Collection of the Auschwitz-Birkenau State Museum in Oświęcim, Poland, ZPMO (= Zbiory Państwowe Muzeum Oświęcim Brzezinka). On the “Arbeitslagermarsch” see Ignacy Szczepański, Häftlingskapelle, 27, 49.

35 SS-photographs (museum and archive Mauthausen in Vienna, Austria, MAM E 20/4 (1), 20/4 (2), 20/7 (1), 20/7 (3) and report MAM E/20/16). See Guido Fackler, "Panoramen von Macht und Ohnmacht. KZ-Bilder als ikoniserte Erinnerung und historisches Dokument”, Helge Gerndt/ Michaela Haibl (eds.): Der Bilderalltag. Perspektiven einer volkskundlichen Bildwissenschaft, vol. 33 of Münchner Beiträge zur Volkskunde (Münster, New York, München, Berlin, 2005), 251-274. 
Auschwitz, and also in Buchenwald, Dachau, Gusen, Mauthausen, Neuengamme, and Stutthof. ${ }^{36}$ It was by no means unusual for SS guards to indulge in some Sunday entertainment at these concerts. These offerings received a somewhat mixed response from the prisoners, though. Some were pleased at the change and gained new courage from the power of music, while others refused to take part in this compulsory exposure to culture as it was a painful reminder of better times.

Finally, in the extermination camps, particularly Birkenau, the prisoner orchestras performed their most inhuman activity, an activity that caused some surviving musicians to experience feelings of guilt and depression for the rest of their lives. Some orchestras had to play directly in connection with the so-called selection process: this was supposed to deceive the newly-arriving prisoners into thinking that they did not face immediate death. Erika Rothschild recalls that these prisoners "were driven out of the cattle trucks and lined up. [...] During this process a band, made up of the best musicians from among the prisoners who were already there, played Polish, Czech, or Hungarian folk music, depending on where the new prisoners were from. [...] some were forced to march into the camp, the rest were driven into the crematorium" ${ }^{37}$ Moreover a few orchestra members had to play near the crematorium at the command of the SS, including the violinist Lili Mathé, Louis Bannet or Schmuel Gogol. ${ }^{38}$ Meanwhile it remains clear that the arrival of new transports, the selections or the walk into the gas chamber were not as a matter of principle accompanied by music, but only occasionally; certainly it happened sometimes in Birkenau that a camp orchestra would appear somewhere in the camp and play music over the new arrivals or selections. ${ }^{39}$ Furthermore it is not known that the killing process itself, that is the mass murder in the gas chambers, took place immediately under the sounds of music.

36 For Auschwitz, see SS-photographs (archive of the Auschwitz-Birkenau State Museum in Oświęcim, Poland, APMO (= Archiwum Państwowe Muzeum Oświęcim Brzezinka) no. neg. fot. 337 und 338); Szymon Laks, Musik in Auschwitz, transl. from Polish by Mirka und Karlheinz Machel, ed. and epilogue by Andreas Knapp, vol. 15 of Schriftenreihe des Fritz Bauer Instituts, Studien- und Dokumentationszentrum für Geschichte und Wirkung des Holocaust (Düsseldorf, 1998), 64; Emil de Martini, Vier Millionen Tote klagen an ...! Erlebnisse im Todeslager Auschwitz (München-Obermenzing, 1948), 36; Musik in Auschwitz. Eine Austellung der Evangelischen Initiative Zeichen der Hoffnung - Znaki Nadziei e.V. in Zusammenarbeit mit der Staatlichen Gedenkstätte Auschwitz-Birkenau, Polen, und der Evangelischen Erwachsenenbildung Frankfurt. Idee und Konzeption: Joachim Martini, Beate Schneppen-Rauer (Frankfurt a. M., 1988), 9, 11, 14. For Buchenwald see Milan Kuna, Musik an der Grenze des Lebens, 55; Sonja Staar, “'Es war dies alles eine schauderhafte Symphonie ...': Die Häftlingskapelle im Konzentrationslager Buchenwald. Ein Streichquartett im Block 22," Zeitschrift der Fura Soyfer Gesellschaft (Wien) 4, no. 4 (1995), 14-21. On Dachau see Rudolf Kalmar, Zeit ohne Gnade (Vienna, n.d. [1988]), 77. On Gusen see Zbigniew Wlazłowski, Przez kamieniołomy i kolczasty drut (Through Stone Quarries and Barbed Wire), (Cracow, 1974). On Mauthausen see interview of Hans Maršálek by the author on 4 April 1994. On Neuengamme see interview of Herbert Schemmel by the author on 3 November 1994. On Stutthof see report of Theodor Traugott Meyer from 13 August 1947, published in Hermann Kuhn, ed., Stutthof. Ein Konzentrationslager vor den Toren Danzigs, transl. Leon Lendzion (Bremen, 1995), 186-190, here 189.

37 "Eine Erinnerung. Ein Gespräch mit Erika Rothschild, die Auschwitz überlebt hat," Badische Zeitung (Freiburg i.Br.), Magazine of the nr. of 21/22 January, 1995, 2. See also Seweryna Szmaglewska, "Rauch über Birkenau (Ausschnitt)," in Adolf Rudnicki, ed., Ewiges Gedenken (Warsaw, 1955), 85-104, here 93-94; Gabriele Knapp, Das Frauenorchester in Auschwitz. Musikalische Zwangsarbeit und ihre Bewältigung, 118, 120-123.

38 See Derrick Sington, Die Tore öffnen sich. Authentischer Bericht über das englische Hilfswerk für Belsen mit amtlichen Photos und einem Rückblick von Rudolf Küstermeier, vol. 3 of Geschichte des Holocaust (Münster, 1995), 139; Verslag van den Heer (report of) Louis Bannet (Rijksinstituut voor Oorlogsdocumentatie in Amsterdam, The Netherlands (= RIOD), OGC), 1; Klaus Sondergeld, "Rückkehr nach 45 Jahren. 'Ein großes Kind.' Eine Auszeichnung für den Musiker Schmuel Gogol”, Die Zeit, no. 29 from July 13,1990.

39 See Laks, Musik in Auschwitz, 64; Shirli Gilbert, Music in the Holocaust: Confronting Life in the Nazi Ghettos and Camps (Oxford 2005), 177-178. 


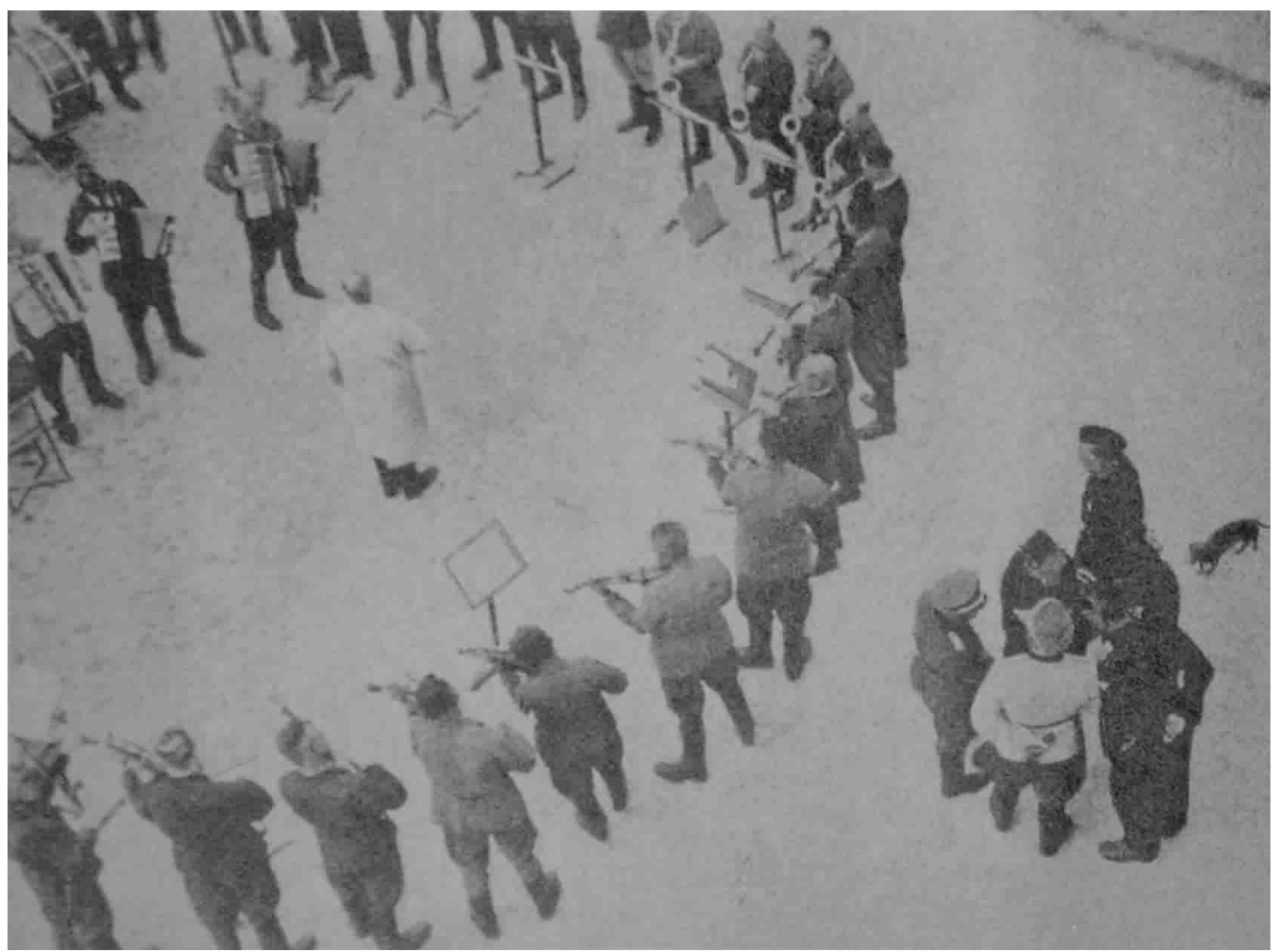

Figure 3. This SS-photograph shows a camp ensemble, probably in the Janowska concentration camp (published in Renzo Vespigniani, Faschismus, ed. Neue Gesellschaft für Bildende Kunst und Kunstamt Kreuzberg (Berlin, 1976), 123)

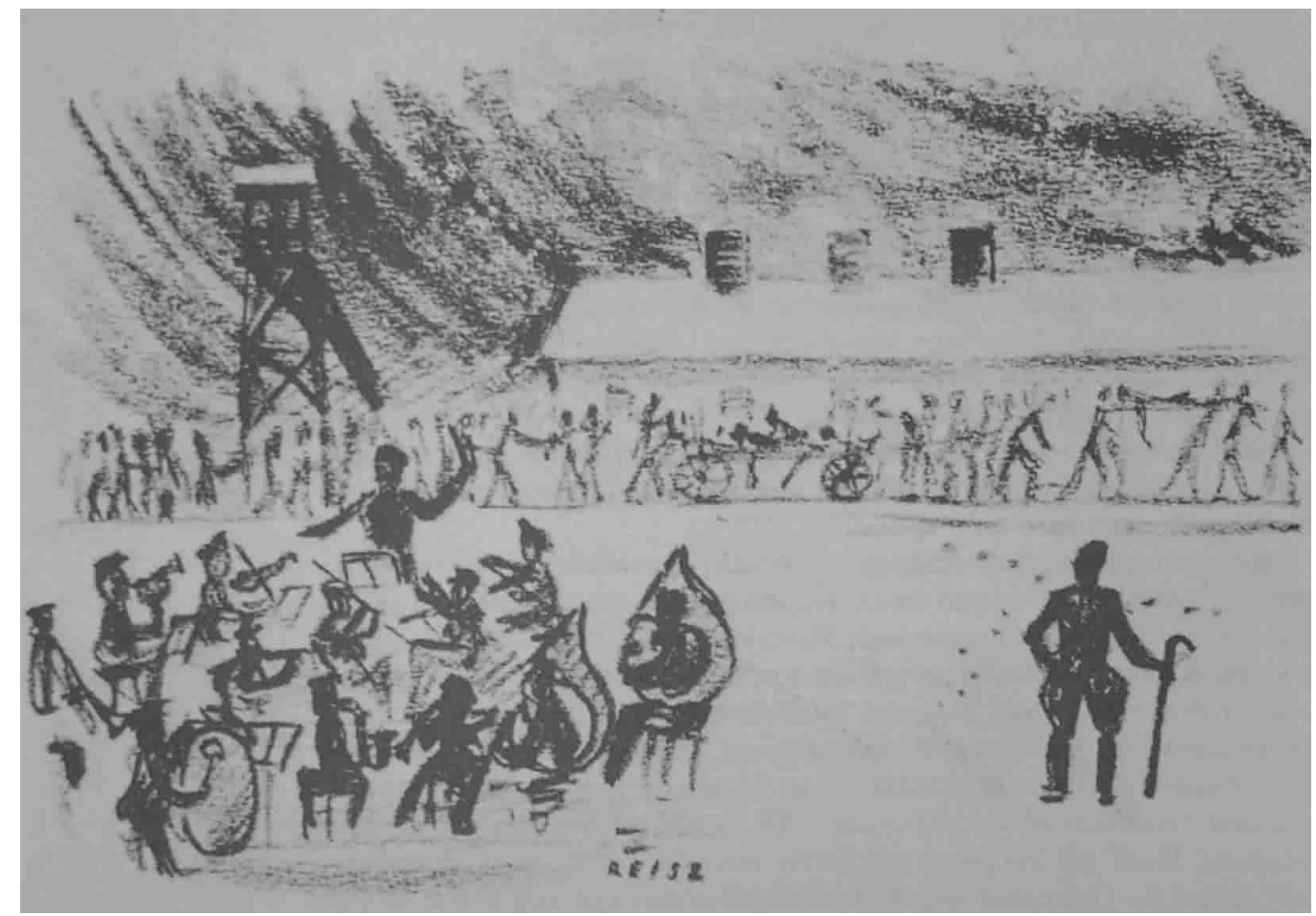

Figure 4. This drawing was made secretly in Birkenau by François Reisz. It shows the camp orchestra playing as work details returns to the camp; they carried out the dead on stretchers and handcarts (published in Projektgruppe Musik in Konzentrationslagern, ed., Musik in Konzentrationslagern (Freiburg i.Br., 1991), 58) 


\section{Music to Entertain the Guards}

As we have seen, music on command was performed mainly in the institutionalized framework of the official daily routine of the camp, but prisoners were also forced to perform on various occasions out of the ordinary run of things. ${ }^{40}$ A sufficient number of cases have shown that some brutal mass murderers were at the same time sensitive music lovers. In other cases the camp authorities, people related to the guards, and high ranking prisoner functionaries did not hesitate to use music to quite deliberately repress and subdue their victims. In choosing prisoners to serve under them, some of these people selected those with musical skills. Like other SS-men, Thies Christophersen, an SS officer (SS-Sonderführer) at Auschwitz, enjoyed what was called "Gypsy music," and so when he was assembling his work detail he favored Gypsies, also known as the Sinti and Roma. ${ }^{41}$ In this way musicians and singers with musical gifts or with a musical training were turned into a sort of personal "musical slaves," available at all times. They can be said to have had a dangerously dependent relationship to the SS or to prisoner functionaries: they could not with impunity refuse to comply with their desire for musical entertainment. On the other hand, their special status provided the musicians with a certain degree of protection from random brutality, and accorded them "privileges" which in some cases ensured their survival. ${ }^{42}$ But as soon as the "musical slaves" had done their duty, all of their protections were taken away.

Often members of the camp orchestras gave private performances for the guards. According to Benedict Kautsky, this was "occasionally" the case at Buchenwald, while it was the "rule" in Auschwitz. ${ }^{43}$ Helena Dunicz-Niwinska reported of her experience in Birkenau: "Works by Grieg, Schumann and Mozart [were played] for the connoisseurs among the ranks of the SS" who came to "relax" after the process known as selection. ${ }^{44}$ Music lovers in the upper ranks of the camp staff were more interested in classical music, while the lower ranks maintained small ensembles comprising members of the official orchestra - or else secured the services of individual musicians - to provide light music for their drinking sessions, orgies and other feasts. Erich Frost was a prisoner in Sachsenhausen because he was a member of the Jehovah Witnesses. He was forced to play on his harmonica whenever the shout went out, "Where is Frost, the musician?" 45 Frost was then forced to play during a New Year's Eve party in the SS casino, and also for "social" evenings held by a block leader. However, his musicianship helped not only himself, but also the entire category of prisoners to which he belonged, enhancing their esteem among the camp staff and thus improving their treatment. On these occasions, members of the SS were sometimes even known to play music together with the prisoners.

40 See Guido Fackler, "Des Lagers Stimme“ - Musik im KZ, 361-368.

41 See the report of the SS-man Thies Christophersen in the documentary film, Komm und sieh. Wahrheit macht freiRechtsradikale in Deutschland (Germany, Sweden, 1992).

42 See, for example, Zofia Posmysz, "Die 'Sängerin'," Hefte von Auschwitz no. 8 (1964), 15-32.

43 Benedikt Kautsky, Teufel und Verdammte. Erfahrungen und Erkenntnisse aus sieben Fahren in deutschen Konzentrationslagern (Zürich, 1946), 222.

44 Report of Helena Dunicz-Niwinska, published in Die Auschwitz-Hefte. Texte der polnischen Zeitschrift "Przeglad Lekarski" über historische, psychische und medizinische Aspekte des Lebens und Sterbens in Auschwitz, ed. Hamburger Institut für Sozialforschung, 2 vols. new ed. (Hamburg, 1994), vol. 2, 145.

45 Report of Erich Frost from March 1971 (histroical archive of the Wachturm-Gesellschaft/ Watchtower Society in Selters, Germany), 77; Manfred Gebhard, ed., Die Zeugen fehovas. Eine Dokumentation über die Wachtturmgesellschaft (Schwerte, 1971 ), quote on 182 , see also 173-187. 


\section{Music Initiated by the Prisoners}

Music on command was one thing. But musical activities resulting from the prisoners' own initiative took on quite a different significance, whether the performance was for the musicians themselves or for their fellow-prisoners. ${ }^{46}$ Such musical experiences, it is true, sometimes awakened memories so painful that they resulted in depression and resignation. However, playing music like this - unlike the command music - generally evoked favorable connotations. Music gave the prisoners consolation, support and confidence; it reminded them of their earlier lives; it provided diversion and entertainment; and it helped them to articulate their feelings and to deal with the existential threat of their situation emotionally and intellectually. Even the least conspicuous ways of making music took on a deep significance in the concentration camp. In this way singing, humming, or whistling served not only as a relaxing way of passing the time, but also helped prisoners in solitary confinement, for instance, to overcome loneliness and fear.

\section{Stages in the Development of a Self-Determined Musical Life}

Even in the early years of the concentration camps, between 1933 and 1936, prisoners had begun to make music on their own initiative: this generally involved just singing and there were very few groups of instrumentalists. The dominant style here was amateur music in the tradition of the youth movement and the workers' movement. The reason for this was that in these years mainly political opponents of the Nazis were imprisoned, and professional musicians were rare among the camp inmates. The standard and scope of musical performance did not improve significantly until the outbreak of the Second World War. At that point, more and more prisoners from a many countries and social classes began to be deported to the camps; and among these prisoners there was a higher proportion of trained musicians, artists and intellectuals. The musical traditions of these groups and nations increasingly enriched the musical life of the camps.

As stated before, this musical life originated from specific traditions and circumstances. Also the prisoners did not only form a homogeneous mass without individual differences or reaction. Their behavior was influenced by the specific requirements of the camp's reality. However it also was shaped by prior cultural processes and dispositions. In this context the historian Falk Pingel distinguished between the experiences that the prisoners made in the concentration camps and their qualities and abilities which they learned before their imprisonment and which they brought into the camps. ${ }^{47}$ Thus - besides the pieces of music which originated in the camps - the prisoners played mostly songs and compositions which they knew from their family, friends, school, and former music lessons, for example.

The rapid increase in prisoner numbers with the outbreak of war is indirectly responsible for the considerably increased opportunity for musical events. The SS were increasingly short of manpower; and to ensure the internal working of the camps they were forced to rely more and more on the assistance of prisoner functionaries to keep the camps going. As a result, the Kapos'

46 See Guido Fackler, “Des Lagers Stimme” - Musik im KZ, 181-290, 303-328 (1933-1936), 368-410 (1936-1945), 411-429 (in general).

47 See Falk Pingel, Häftlinge unter SS-Herrschaft. Widerstand, Selbstbehauptung und Vernichtung in Konzentrationslagern, vol. 12 of Historische Perspektiven (Hamburg, 1978), 10, 13. See also Guido Fackler: "Des Lagers Stimme“ - Musik im KZ, 457-462. 
influence on prison conditions grew. These prisoner functionaries, particularly those classified as criminals (Berufsverbrecher), frequently abused the powers entrusted to them, mistreating those fellow-prisoners under their authority. But other Kapos, usually those classified as political prisoners, used their position to the benefit of their fellow-prisoners, so that a block elder (Blockältester) might permit a sing-song in the evening, or one of the prisoners' representatives in the camp might get the SS to grant permission for a musical performance.

Musical activities were at their most widespread from 1942/43 on. During this period, prison labor was used in the arms-industry. At the same time, the concentration camp system expanded by building satellite camps. In connection with the "bonus-system" already mentioned this brought the prisoners certain "privileges” from the SS. These concessions, of course, were designed primarily to increase the work output and to forestall disturbances - and in any case affected predominantly German inmates, prisoner functionaries, and "prominents". However, as a result of such concessions, it became easier to procure instruments and sheet music from outside, set up a few musical groups, give concerts, and organize such other cultural events as theater or cabaret performances.

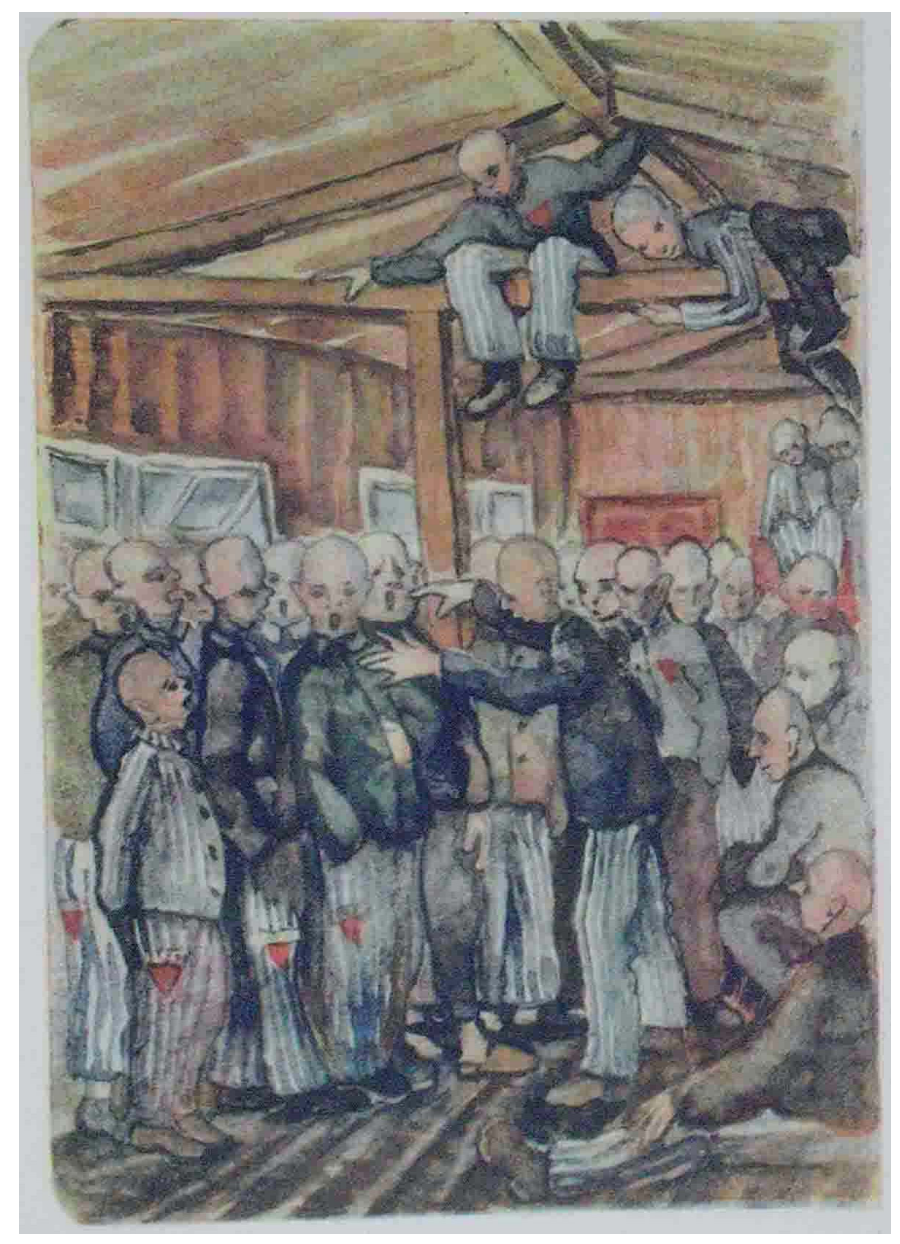

Figure 5. In 1942 in Dachau, an evening of song given by the Czechoslovakian camp choir was recorded in this drawing by Vladimir Matejka. The huge crowd enjoying this rare musical treat shows clearly how important it was for prisoners to be able to organize a musical performance like this (published in Kopf hoch, Kamerad! Künstlerische Dokumente aus faschistischen Konzentrationslagern, ed. Deutsche Akademie der Künste zu Berlin, 2d ed. (Berlin, 1966), ill. 21). 
In particular during the years 1942/43 many camps saw the development of very different kinds of musical ensembles, some within a single group of prisoners, some with prisoners from different groups and nationalities. One of the musical formations in Buchenwald was a Jazz Big Band; in Sachsenhausen there was a mouth-organ group; in Falkensee played a "gypsy orchestra"; and a choir of Soviet prisoners of war performed in Flossenbürg. ${ }^{48}$ Let us consider Dachau to illustrate how varied the musical life of a concentration camp could be when prisoners took the initiative. One of them, Herbert Zipper, was a conductor, a composer and a music teacher. As early as 1938 he formed an orchestra which secretly gave concerts for fellow-prisoners. ${ }^{49}$ In February 1941 the SS gave permission for a twenty-eight-member prisoners' orchestra; in 1942 there was a fifty-man orchestra performing a program of classical music, as well as a special Polish orchestra; in addition there was a string quartet, a chamber music ensemble, a Czech light orchestra, together with various soloists, choirs and vocal groups. ${ }^{50}$ Furthermore, a theater group performed in 1943 accompanied by music. ${ }^{51}$

In most camps, professional musicians or talented amateurs established musical groups. Some of these lasted only for a short time; others lasted longer; some rehearsed regularly, others only as opportunity arose; some performed spontaneously, while others performed concerts where the artistic standard was very high. Music composed in the camp itself was also performed. Among the factors often preventing rehearsals and performances were the poor physical condition of the prisoners, language barriers among prisoners, the danger of being discovered, personnel changes due to deportations, and the lack of instruments and sheet music; it was often necessary to organize these secretly, or to play from memory. These difficulties made it all the more important for professional and amateur musicians to set an example of solidarity and humane behavior in their dehumanized surroundings. This meant, of course, that there was less emphasis on aesthetic criteria: through fostering a sense of community, music served instead as a form of cultural resistance, as practical assistance in the struggle to survive.

It is widely - but erroneously - believed that the prisoners were never allowed to play music themselves in the concentration camps. It is true that music with a political content, and other kinds of forbidden music were not allowed. This kind of music could only be played in secret, and at the constant risk of being discovered and punished. According to Walter Wolf, this was the experience of a string quartet in Buchenwald concentration camp: "Jewish comrades [...] were playing passages from Mozart's 'Eine Kleine Nachtmusik'. [...] The SS found out, and our Jewish comrades were put

48 On Buchenwald see Wolfgang Muth, “'Rhythmus' - Ein internationales Jazzorchester in Buchenwald,” in Eisenacher Fazztage 1984. 25 Fahre AG Fazz im Klubhaus AWE (Eisenach, 1984), 10-15; Guido Fackler, "Jazz im KZ. Ein Forschungsbericht," in Wolfram Knauer, ed., fazz in Deutschland. Eine Veröffentlichung des fazz-Instituts Darmstadt, vol. 4 of Darmstädter Beiträge zur Fazzforschung (Hofheim, 1996), 49-91, here 53-58. On Sachsenhausen see Report of Otto Bartels (archive of Gedenkstätte und Museum Sachsenhausen/ Memorial and Museum Sachsenhausen in Oranienburg, Germany, R 41/4/3), 2. On Falkensee see Aleksander Kulisiewicz, "Polskie pieśni obozowe 1939-1945" (Polish Concentration Camp Songs 1939-1945) (unpublished manuscript at the private archive of Krzysztof Kulisiewicz in Cracow, Poland, 1982), 799. On Flossenbürg see Hugo Walleitner, Zebra. Ein Tatsachenbericht aus dem Konzentrationslager Flossenbürg. Mit 34 Bildern des Verfassers (Bad Ischl, 1946), 87.

49 Paul F. Cummins, Dachau Song. The twentieth-century Odyssey of Herbert Zipper (New York et al., 1992), 85-87.

50 See Aleksander Kulisiewicz, "Polskie pieśni obozowe 1939-1945”, 575-633; Guido Fackler, "Musik im KZ Dachau," in Josef Focht and Ursula K. Nauderer, eds., Musik in Dachau (Dachau, 2002), 179-192.

51 See Rudolf Kalmar, Zeit ohne Gnade, 173-187. 
over the flogging horse; each got 25 strokes for the crime of playing German music as Jews ".52 However, most of the musical performances organized by the prisoners were expressly permitted or at least tolerated by the SS. Other musical activities took place in a semi-legal context, in a greyzone, as when the Czech vocal group the "Sing-Sing-Boys" performed. A member of the audience who survived described the situation thus: "The performances [...] were to some extent legal, to some extent illegal, because songs were sung which at that time were forbidden in the Protectorate [at that time Bohemia and Moravia in Czechoslovakia were a protectorate of the German Reich]. [...] There was no applause; it would have been too dangerous. In our hearts we applauded. There were often encores, but that depended on the situation in the camp" ${ }^{53}$

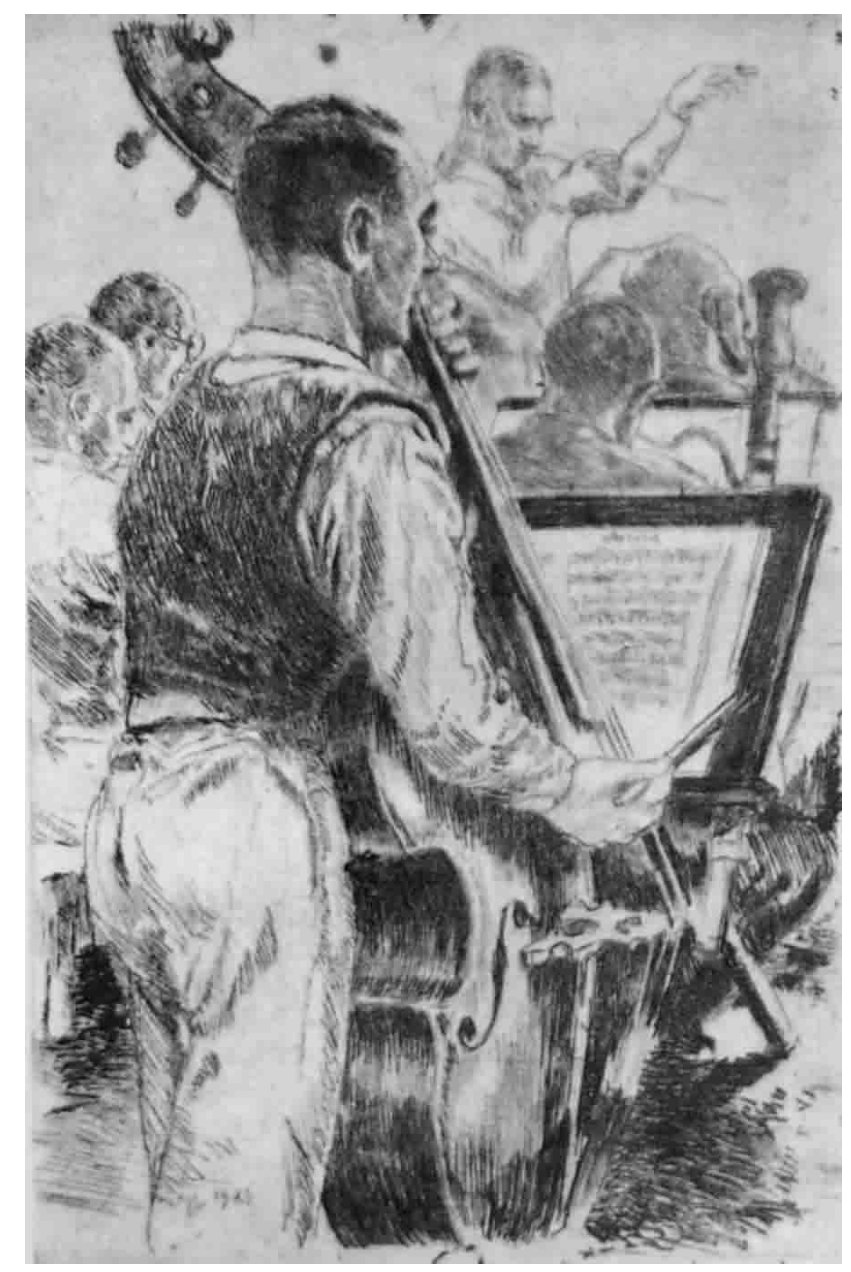

Figure 6. The official camp orchestras often provided an important impulse in the field of instrumental music. Thus, those involved in the camp ensembles often formed other music groups, and maximum use was made of the available instruments. Besides, other prisoners frequently formed the audience for concerts or rehearsals by the camp orchestras, as we see here in this etching made by Mieczysław Koscielniak under the title "Adam Kopycinski - concert" in Auschwitz in 1943. Published in M. Koscielniak: Bilder von Auschwitz, 2d ed. (Frankfurt a. M., 1986), n.p. Adam Kopycinski conducted the camp orchestra of the main camp of Auschwitz.

52 Walter Wolf, "Musik im Konzentrationslager Buchenwald" (archive of the Gedenkstätte Buchenwald/ Buchenwald Memorial in Weimar, Germany, BwA 9-98-15), 2.

53 Unpublished letter from Josef Sárka to the author from 29 December 1990, 1. 


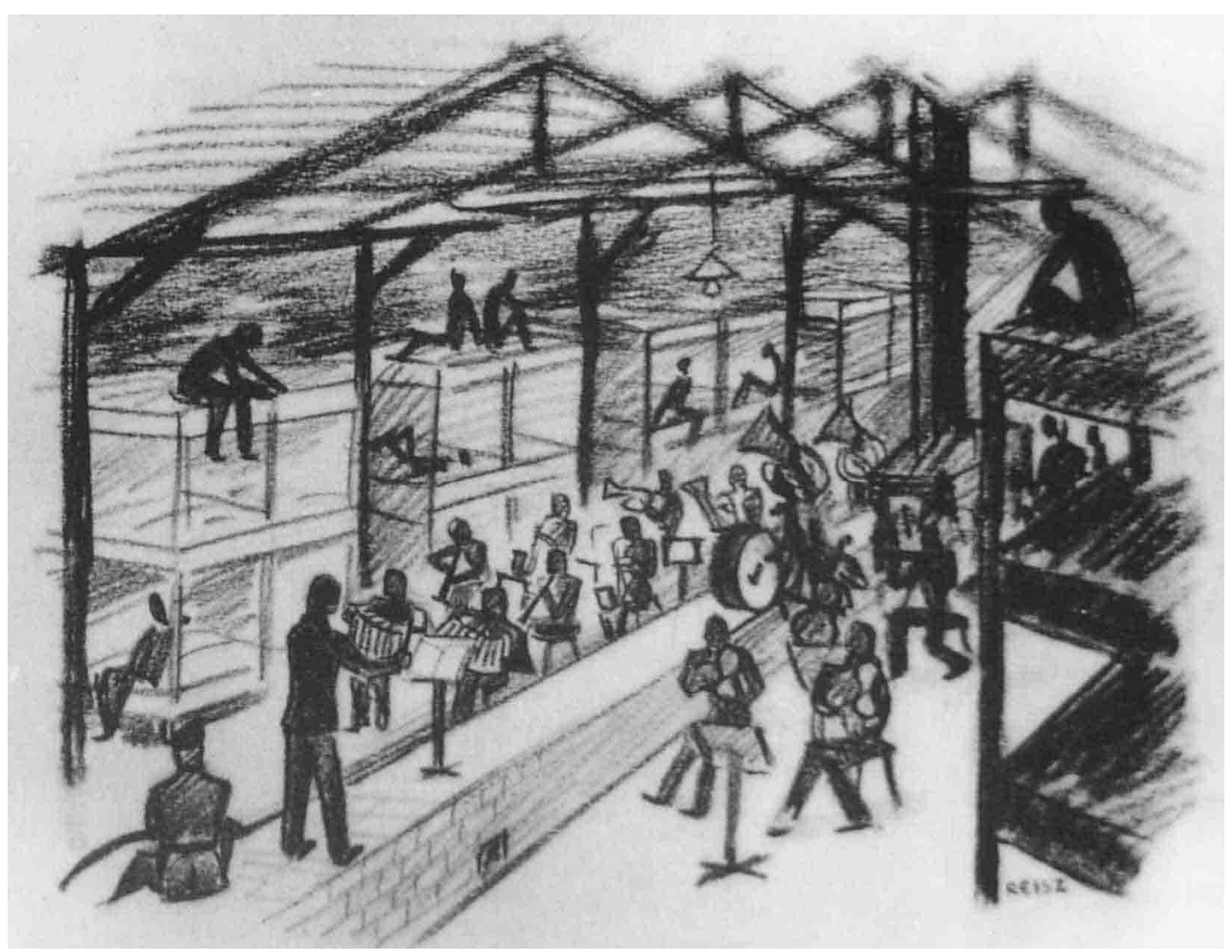

Figure 7. Concert of a camp orchestra in a prisoner-hut under presence of a SS-man (left). Drawing of François Reisz, originated in the extermination camp Auschwitz-Birkenau. Published in Guido Fackler, "Des Lagers Stimme" - Musik im KZ. Alltag und Häftlingskultur in den Konzentrationslagern 1933 bis 1936. Mit einer Darstellung der weiteren Entwicklung bis 1945 und einer Biblio-/ Mediographie, vol. 11 of DIZ-Schriften (Bremen, 2000), ill. 28.

So far I have established, in general terms, the fact that prisoners managed to play music for themselves, despite the limited freedom of operation and the extreme conditions in the camps. In conclusion, I will discuss in somewhat more detail, the various forms these activities typically took.

\section{Spontaneous Music}

Most musical activities in concentration camps and extermination camps took place without much preparation: groups of friends and acquaintances struck up spontaneously. While there were occasions when instrumental music was played in this fashion, or instruments were used to accompany singing, the dominant feature here was unaccompanied unison singing in groups. ${ }^{54}$ In Majdanek, an extermination camp, a prisoner from the Operetta Theater in Vilna started singing arias from operas, songs from operettas, and Russian and Ukrainian songs. ${ }^{55}$ This led his comrades

54 See Guido Fackler, "Des Lagers Stimme“- Musik im KZ, 194-208 (1933-1936), 304 (definitions), 384-387 (1936-1945), 307321 and 387-398 (songs and singing); Guido Fackler, "Lied und Gesang im KZ".

55 See Zacheusz Pawlak, “Ich habe überlebt ..”.. Ein Häftling berichtet über Majdanek, 152. 
to take up the song and accompany him softly in a chorus. Spontaneous singing like this attracted little or no attention; it could be done by anyone at any time, and required neither sheet music nor rehearsal, nor a special opportunity for a performance.

When prisoners began to sing spontaneously like this, they generally sang familiar songs and songs that the prisoners involved could identify with: they served well to enhance the sense of community. Other kinds of songs were heard as well - mainly folk songs from the various regions and countries the prisoners came from. Thus prisoners being marched to the gas chambers in Birkenau sang the Czech national anthem, or the Jewish song "Hatikvah:" in this way they expressed their protest, and showed that they had not been broken. ${ }^{56}$ The fighting words in other songs made them popular too; such songs were traditionally associated with resistance and freedom, partisans' songs, and political songs. Among German-speaking prisoners, the song "Die Gedanken sind frei" ("Thoughts are free") became one of the most important. ${ }^{57}$ While Polish prisoners attached great symbolic importance to the Polish revolutionary song "Warschawjanka," 58 for Jewish prisoners this role was taken on by the partisans' song "Zog nisht keyn mol," ${ }^{9}$ which had been composed by Hirsh Glik ${ }^{60}$ in the Vilna ghetto camp. Many popular songs were secretly collected in specially hand-made song-books (KZ-Liederbücher) - often tastefully decorated - to serve as memoirs, or as gifts, for instance, to a prisoner functionary. ${ }^{61}$

56 See Tzvetan Todorov, Angesichts des Äußersten, transl. from French by Wolfgang Heuer und Andreas Knop (München, 1993), 71.

57 The text from an unknown writer appeared first between 1780 und 1800 in song leaflets (Liedflugschriften) while the melody is verifiable since 1810. Achim von Arnim und Clemens Brentano published the song as "Zwiegesang zwischen einem Gefangenen und seinem Mädchen" ("Duet between a prisoner and his Girl") in their famous song collection Des Knaben Wunderhorn (1806/1808). Thereafter, the song was continually censored. On the use of this song for example in the concentration camps Heuberg, Gotteszell, Ravensbrück or Sachsenhausen see Fred Rieckert, "Erlebnisbericht aus den Konzentrationslagern Heuberg und Kuhberg", written in American POW center (PW Center 5) on 30 April to 1 August 1945 (archive of the Dokumentationszentrum Oberer Kuhberg/ Documentation Center Oberer Kuhberg in Ulm a.d. Donau, Germany), 25; Julius Schätzle, Stationen zur Hölle. Konzentrationslager in Baden und Württemberg 1933-1945, ed. on contract from the Lagergemeinschaft Heuberg-Kuhberg-Welzheim (Frankfurt a. M., 1974), 26; Charlotte Müller, Die Klempnerkolonne in Ravensbrück. Erinnerungen des Häftlings Nr. 10.787 (Frankfurt a. M., 1981), 182; Isa Vermehren, Reise durch den letzten Akt. Ravensbrück, Buchenwald, Dachau: Eine Frau berichtet (Reinbek, 1998), 147; Eberhard Schmidt, Ein Lied - ein Atemzug. Erinnerungen und Dokumente, 127.

58 The text was written in 1883 by the "revolutionary" poet, Wacław Swięcicky, to the 1863 melody of a Polish song of freedom. See Inge Lammel, Das Arbeiterlied (Frankfurt a. M., 1973), 109-110, 224; Wojciech Mszyca, “ 'Warszawianka' za drutami” (archive of the KZ-Gedenkstätte Dachau/ Dachau Memorial in Dachau, Germany, file "Musik, verschiedene Lieder").

59 Hirsh Glik wrote the song "Zog nisht keyn mol" (also "Zog nit keinmol," "Zog nisht keynmol az du geyst dem letsten verg," "Sog nischt kejnmol" or "Zog nit keyn mol"), which became a partisan hymn after the Warsaw Ghetto uprising of 19 April 1943. The music is adapted from a melody of the Russian composer, Dmitry Pokrass. Hirsh Glik was deported from the Vilna ghetto to a camp in Estonia where he died in 1944. See Songs of the Ghetto. Collected and Arranged by Henech Kon, vol. 2. (New York, 1972), 1. On the use of this song in concentration camps see Josef Katz, Erinnerungen eines Überlebenden (Kiel, 1988), 140, text partially remembered wrong.

60 See Nachman Mayzel [Meisel], Hirsh Glik. Lider un Poemes (Songs and Poems) (New York, 1953); M. Dworzecki, Hirsch Glik. The Author of the Jewish Partisan Hymn (Paris, 1966); Lutz van Dick, Der Partisan. Das kurze Leben von Hirsch Glik, afterword by Esther Bejarano (Reinbek, 1993); Yehiel Szeintuch, "Glik, Hirsh," in Enzyklopädie des Holocaust. Die Verfolgung und Ermordung der europäischen fuden, eds., Israel Gutman, Eberhard Jäckel, Peter Longerich, and Julius H. Schoeps, 3 vols. (Berlin, 1993), vol. 1, 544-545.

61 See Aleksander Kulisiewicz, "Polskie pieœni obozowe 1939-1945," 22-24; Inge Lammel, "Das Sachsenhausen-Liederbuch," in Günter Morsch, ed., Sachsenhausen-Liederbuch, 14-31; Guido Fackler, "Des Lagers Stimme“ - Musik im KZ, 201-202, 207208, 318-319, 394-395; Juliane Kunze, "Gesang als Überlebensstrategie im Konzentrationslager Sachsenhausen”; Shirli Gilbert, "Songs Contest the Past: Music in KZ Sachsenhausen," Contemporary European History 13 (2004), no. 3, 281-304, here 285286. The following song-books from Sachsenhausen are published as reprints: Das Lagerliederbuch. Lieder, gesungen, gesammelt und geschrieben im Konzentrationslager Sachsenhausen bei Berlin 1942, 4th ed. (Dortmund, 1983) [birthday-gift for 
A large number of new songs called KZ-Lieder (concentration camp songs) were composed in the camps themselves (for example, "The Peat Bog Soldiers"), often at great risk and under very difficult conditions. ${ }^{62}$ Most of these songs consisted of contrafacts or song parodies in which a familiar melody was given a new text. The content generally attempted to deal with the reality of life in the camps, the depressing situation the prisoners found themselves in, the harsh conditions of life, or the fears and hopes of the inmates. For example, the popular German song "Wo die Nordseewellen trecken an den Strand" ("Where the North Sea waves make to the sandy shore"), also called simply "Nordseewellen" ("North Sea Waves") ${ }^{63}$ was given a new text in the North German Emsland camps, where its title became "Wo das Lager steht" ("Where the camp stands"). ${ }^{64}$

This song was part of the repertoire of Aleksander Kulisiewicz. ${ }^{65}$ He was one of the so-called Lagersänger (camp singer) in Sachsenhausen, who were known throughout the camp as songwriters and performers. ${ }^{66}$ The songs he sang for his fellow-prisoners were generally camp songs, whose texts and often their melodies were composed in the camp. Among these songs was his "Choral aus der Tiefe der Hölle" ("Hymn from the depths of hell”), in which revenge is sworn on the executioners: "hört unseren choral / aus der tiefe der hölle! / er soll unseren henkern / auf ewig die träume stören!" ("hear our hymn / from the depths of hell! / let it ever trouble / the dreams of our executioners!”). ${ }^{67}$ After he was liberated, Kulisiewicz collected 374 Polish songs from various camps. His unique collection of documents relating to the musical and artistic life in the camps is at present deposited in the United States Holocaust Memorial Museum in Washington D.C. ${ }^{68}$ It is thought -

Willy Feiler in 1943]; Günter Morsch, ed., Sachsenhausen-Liederbuch. Originalwiedergabe eines illegalen Häftlingsliederbuches aus dem Konzentrationslager Sachsenhausen, comments on the Reprint by Inge Lammel (Berlin, 1995).

62 See Guido Fackler, "Des Lagers Stimme" - Musik im KZ, 235-290, 335-340, 394-398. A wide range of camps songs is documented in a new 3-cd-collection: Fietje Ausländer, Susanne Brandt and Guido Fackler, „O Bittre Zeit. Lagerlieder 1933 bis 1945“, ed. Dokumentations- und Informationszentrum (DIZ) Emslandlager, Papenburg, in cooperation with musik archive of Akademie der Künste, Berlin, and Deutsches Rundfunkarchiv (DRA), Potsdam-Babelsberg/Wiesbaden (Papenburg, 2006, ISBN 978-3-926277-14-5, e-mail: online URL: http:/www.diz-emslandlager.de/cd03.htm ).

63 Friedrich Fischer-Friesenhausen wrote the song "Wo die Nordseewellen trecken an den Strand," first printed in 1922. It was based on a reworking - like other pastoral versions - of "Wo die Ostseewellen trecken an den Strand," of the "Pommernlied" that was originally composed in 1907/08 by Martha Müller-Grählert and set to music by Simon Krannig between 1908 and 1910. "Wo die Nordseewellen trecken an den Strand" was gladly sung by German priosners in the concentration camps. See for example, Das Lagerliederbuch. Lieder, gesungen, gesammelt und geschrieben im Konzentrationslager Sachsenhausen bei Berlin 1942, 132. It also served as the basis for other camp songs, which for example, stemmed from the Soviet Union or in East European camps established for Germans after the end of World War Two, for example, in the "girls" camp" of Kriwoj Rog in the Soviet Union or in East European camps set up after the war for persecuted Germans. See the song collection A 195.375 (Deutsches Volksliedarchiv/ German Folk-Song-Archive in Freiburg i.Br., Germany); Gottfried Habenich, Leid im Lied. Südost- und ostdeutsche Lagerlieder und Lieder von Flucht, Vertreibung und Verschleppung, preface by Gustav Wabro (Freiburg i.Br., 1996), 436-438.

64 See Lieder aus den faschistischen Konzentrationslagern, 29-30; Guido Fackler, "Des Lagers Stimme"- Musik im KZ, 270-271.

65 He recorded the song "Wo das Lager steht" on his LP Alec Kulisiewicz. Deutsche KZ-Lieder. Polnische KZ-Lieder (label: Die Schallplatte/ Muza, Poland, 1981).

66 On Aleksander Kulisiewicz and his collection see Guido Fackler, "Des Lagers Stimme" - Musik im KZ, 480-487, 517, 525526, 545-550. On the camp singers, see ibid., 397-398; Aleksander Kulisiewicz, "Polskie pieœni obozowe 1939-1945," 24-28. The essays of Aleksander Kulisiewicz about music and songs in concentration camps will be published in german translation. See Guido Fackler, ed., Aleksander Kulisiewicz: Musik aus der Hölle, vol. 4 of Kulturtransfer. Alltagskundliche Beiträge (Würzburg: Königshausen \& Neumann, 2007). Generally on songs and music in Sachsenhausen see Shirli Gilbert, "Songs Contest the Past: Music in KZ Sachsenhausen"; Shirli Gilbert, Music in the Holocaust, 99-143.

67 Lyrics: Leonhard Krasnodebski (1942, KZ Sachsenhausen), melody: Aleksander Kulisiewicz (1944, KZ Sachsenhausen). See Carsten Linde, ed, KZ-Lieder. Eine Auswahl aus dem Repertoire des polnischen Sängers Alex Kulisiewicz (Sievershütten, 1972), 13.

68 See online URL: http://www.ushmm.org/museum/exhibit/online/music/detail.php?content=kulisiewicz (Kulisiewicz Collection) and http://www.ushmm.org/museum/exhibit/online/music/ (music in camps in general). 
and the nature of this collection lends weight to the suggestion - that researchers today are aware of only a fraction of all the concentration camp songs that were sung. ${ }^{69}$

\section{Block Performances}

In contrast to the spontaneous music the so-called block performances (Blockveranstaltungen) generally took place in accommodation huts or barracks with a large number of participants, and they required a certain amount of organization and preparation. ${ }^{70}$ They usually consisted of talks, short performances and vocal interludes, sometimes accompanied by instruments, and they generally took place "after hours" when the SS-men had withdrawn from the camp, leaving the prisoners largely to their own devices.

The block performances were more for private occasions, improvised celebrations on birthdays, or when a prisoner was to be released, or other days with a personal significance. In the Börgermoor concentration camp in the fall of 1933, each block held a farewell party (Barackenabschiedsfest) for any prisoner from that block who was to be released. ${ }^{71}$ On the evening before, the block elder held a speech, everybody sang together, and after he had been given presents, the prisoner due for release was asked to pass on messages to the outside world.

Politically-motivated block performances, on the other hand, could only be held secretly. At these celebrations, a small number of the initiated would come together on important days for the labor movement such as May 1st, or the anniversary of the death of important labor leaders, but members would have to keep watch outside the room where the meeting took place. On 7 November 1933 an illegal prisoners' committee of the Börgermoor concentration camp arranged a secret celebration to mark the sixteenth anniversary of the October Revolution before the evening roll call in all ten huts, where the workers' song "Die Internationale" ("Internationale") was sung. ${ }^{72}$

Because block performances generally took place within specific groups of prisoners, they powerfully reflect the many cultures represented among the national, ethnic and other groups of prisoners. Among the national groups that were musically most active were the Polish and Czech prisoners. ${ }^{73}$ Christian clergy imprisoned in Dachau, also played a special role in keeping up musical activities once the camp commander had granted permission in the early 1940s to say mass or hold services. The Benedictine priest, Father Gregor Schwake, was a key figure in providing a musical framework for worship; to this end he composed various sacred works including a mass ("Dachauer Messe"), in September 1944, and an "Ostertrio" ("Easter Trio") in March 1945 for violin, viola and

69 In general, see Guido Fackler, "Zur besonderen Quellensituation bei der Erforschung von Musik im NS-Lagersystem," mr-Mitteilungen (ed. musica reanimata e.V., Berlin) no. 39 and 40 (2001), part 1: no. 39, 8-24; part 2: nr. 40, 15-29.

70 See Guido Fackler, “Des Lagers Stimme“ - Musik im KZ, 208-212 (1933-1936), 305 (definition), 323-328, 399-405 (19361945).

71 See Wolfgang Langhoff, Die Moorsoldaten, 243, 263.

72 See "Revolutionsfeier hinter Stacheldraht. Wie wir den 16. Jahrestag der Oktober-Revolution im Konzentrationslager Börgermoor feierten," Gegenangriff no. 45 (1934), 7 November 1934, 5; Falk Pingel, Häftlinge unter SS-Herrschaft. Widerstand, Selbstbehauptung und Vernichtung in Konzentrationslagern 249, note 115; Wolfgang Langhoff and Karl Schabrod, "Wir sind die Moorsoldaten," in Der rote Großvater erzählt. Berichte und Erzählungen von Veteranen der Arbeiterbewegung aus der Zeit von 1914-1945, ed. Erasmus Schöfer together with Düsseldorfer Werkstatt des Werkkreises and WerkkreisLektorat (Berlin, 1983), 138-163, here 155; Wolfgang Langhoff, Die Moorsoldaten, 238-239; Heinrich Pakullis, "Von Börgermoor bis Neuengamme. Zwölf Jahre deutsches Konzentrationslager" (archive of the KZ-Gedenkstätte Neuengamme/ Neuengamme Memorial in Hamburg-Neuengamme, Germany, NG 2.8), 2.

73 See Guido Fackler, "Des Lagers Stimme“ - Musik im KZ, 369, 395. 
cello. $^{74}$ This kind of "privilege" was accorded only very rarely to members of other religious groups like Jews or Jehovah Witnesses. Nevertheless they, too, met in secret to worship, and strengthened their faith by praying together and singing sacred music.

\section{Camp or Cultural Performances}

Finally there is a form of musical entertainment which was open to most all the inmates of a camp. Several camps held Christmas parties or cabaret evenings, or events similar to circus performances or variety shows. They consisted of different numbers or sketches, with vocal or instrumental musical interludes. These events were called camp performances (Lagerveranstaltungen), or cultural performances (Kulturveranstaltungen). All inmates were allowed to attend, which meant that the performances were international in character, with members of different groups taking part. The organizational effort, and the numbers taking part, made it impossible to conceal them from the SS, unlike the block performances. They generally took place with the knowledge and permission of the SS; but this in turn meant that the program and texts were subject to censorship. Those in command pursued a dual purpose in sanctioning events like these: on the one hand, in making these concessions they sought to forestall unrest among the inmates, while on the other hand they were providing the guards, who were often present, with a certain amount of entertainment and diversion from their duties.

One of the very first of these camp performances was entitled "Zirkus Konzentrazani" ("Concentration Circus"): it took place in the Börgermoor camp on 27 August $1933 .{ }^{75}$ The SS had inflicted some night-time beatings, and in response, to cheer everybody up, under the leadership of Wolfgang Langhoff - an actor - the inmates secured permission from the camp authorities to put on an interdisciplinary, artistic-comic show. A type of circus ring was set up in Block 5: a viennese trio (Schrammelkapelle) consisting of an accordion, a homemade violin and a Turkish crescent, opened the program and performed during the intervals. Among the number put on were, a ringmaster, a wrestler, acrobats, boxing, clowns, prisoners dressed up as women, and a barbershop quartet. The Grand finale consisted of the première of the "Börgermoorlied" ("The Peat Bog Soldiers"), and the audience of prisoners enthusiastically responded when they were invited to join in. This circus performance was humorous and sometimes irreverent: it portrayed the cares and afflictions of the prisoners, and it directed criticism and irony at the conditions in the camp, while indirectly satirizing the primitive nature of the guards who were present. ${ }^{75 \mathrm{a}}$

74 See Eleonore Philipp, "Priesterkomponisten im KZ Dachau. Musikalisches Wirken 1941-1945," Amperland. Heimatkundliche Vierteljahresschrift für die Kreise Dachau, Freising und Fürstenfeldbruck 32, no. 1 (1996), 242-248; Guido Fackler, "Des Lagers Stimme" - Musik im KZ, 403-405, 408-409; Eleonore Philipp, "Geistliche Musiker im Konzentrationslager Dachau", in Josef Focht and Ursula K. Nauderer, eds., Musik in Dachau (Dachau, 2002), 193-203. See also Gregor Schwake, "Kirchenmusik im Konzentrationslager Dachau," Der Chorwächter. Zeitschrift für Kirchenmusik. Organ der Schweizerischen Cäcilienvereine (Einsiedeln) 71 (1946), 9-12. Gregor Schwake reports under the rubric "Ten Years Ago" from January 1954 to April 1955 in the journal Singt dem Herrn. Sängerblatt des ACV für Deutschland, Österreich und die Schweiz (Cologne) on his musical activities in the Dachau camp. Meanwhile a recording of Schwake's mass has appeared as music tape in Germany under the title Gregor Schwake: Dachauer Messe. In viam pacis. Regina pacis (conductor: Anton Roth; Meckenbeuren 1998).

75 See Wolfgang Langhoff, Die Moorsoldaten, 165-186, see also 136-155; Richard Albrecht, “'Zirkus Konzentrazani': eine Modellanalyse," Österreichische Zeitschrift für Soziologie 9, no. 1/2 (1984), 183-190; Guido Fackler: "Des Lagers Stimme"Musik im KZ, 214-220, 223-224.

75a See Guido Fackler, “Des Lagers Stimme”- Musik im KZ, 217-219. 
Other concentration camps also had camp performances: there were lecture evenings in Börgermoor, evenings of song in Sachsenburg and Lichtenburg, and variety shows in Dachau. ${ }^{76}$ During the war years, camp performances were held fairly regularly, especially in "old" concentration camps with relatively well-established structures and hierarchies. Here for instance secret resistance committees were established or respected political prisoners took on informal leadership roles within the camp such as camp elder (Lagerältester) or camp scribe (Lagerschreiber). There is also evidence that performances like these took place in eastern European camps too, where conditions were "considerably worse" 77 than those in the more westerly camps. As evident from a program from the Stutthof concentration camp female prisoners held an afternoon entertainment on 16 January $1944 .^{78}$

In Dachau, during the final years of the war, so-called "concerts" were put on in the bath house, with official permission, almost every weekend, sometimes on Saturday and Sunday afternoon. ${ }^{79}$ In addition to a large string orchestra the performers included chamber music groups, choirs, and soloists. ${ }^{80}$ The equivalent performances in Buchenwald were very different, consisting more of variety programs with a number of different turns. ${ }^{81}$ These performances were put on in a hut that had been turned into a cinema. Between 1 August 1943 and 31 December 1944, a total of twenty seven "concerts" took place at this venue: they were permitted, or at least tolerated, by the camp authorities. An announcer provided continuity through the show, which consisted of musical performances, but also sketches, gymnastic and artistic displays, as well as cabaret and theater. The program was put together by a "committee with representatives from all the nations with numerically strong contingents in the camp“. ${ }^{82}$ On all these occasions, the jazz Big Band "Rhythmus" ("Rhythm") played, and the trombone part for Glenn Miller's "In The Mood" - under the Nazis a so-called piece of "degenerate Music" - has been preserved. ${ }^{83}$ Performances like these also became an occasion to compose new pieces; and at Christmas and New Year 1943/44 an opera was performed in the pathology rooms, entitled "Buchhäuser oder Läusekrieg auf der Waldburg" ("The Denizens of Buchenwald House, or the Lice war of Waldburg"). ${ }^{84}$ It told the story of the prisoners' battle against lice, but the lice symbolized the SS.

76 See Guido Fackler, “Des Lagers Stimme“ - Musik im KZ, 213-235 (1933-1936), 305 (definition), $405-410$ (1936-1945).

77 Gudrun Schwarz, "Frauen in Konzentrationslagern" (unpublished protocol (Tutzing, 1995) of the seminar " "Vergangen ist weder ein Tag, noch sind es die Nächte’' Frauen im Konzentrationslager“ 25 to 28 May 1995 in Tutzing, Germany, organized by Evangelische Akademie, Tutzing and Topographie of Terror, Berlin), 24-41, quote on 38.

78 See Guido Fackler, "Des Lagers Stimme" - Musik im KZ, ill. 31.

79 Interview of Franz Brückl [formerly Przybylsky] by the author on 23 May 1995.

80 See Rudolf Kalmar, Zeit ohne Gnade, 77; Interview of Hans Gasparitsch by the author on 10 October 1995.

81 See Wolfgang Schneider, Kunst hinter Stacheldraht, 71-78; Buchenwald. Mahnung und Verpflichtung. Dokumente und Berichte, ed. on order of the Fédération Internationale des Résistants (FIR) by the Internationale Buchenwald-Komitee of the Antifaschistischen Widerstandskämpfer in the Deutschen Demokratischen Republik, 3rd ed. (Berlin, n.d.), 459-461. See also Sonja Seidel: Kultur und Kunst im antifaschistischen Widerstandskampf im Konzentrationlager Buchenwald; Sonja Staar, Kunst, Widerstand und Lagerkultur. Eine Dokumentation.

82 Report nr. 28 "Kunst im K.L. Bu". of Collection Otto Halle (archive of the Gedenkstätte Buchenwald/ Buchenwald Memorial in Weimar, Germany), 2 (=13).

83 Published in Wolfgang Muth, “'Rhythmus' - Ein internationales Jazzorchester in Buchenwald,” 11 . See also note 48 and interview of Miroslav Broft by the author on 8 May and 12 May 1996.

84 Reports of Wacław Czarnecki, Zygmunt Zonik and Internationales Lagerkomitee. Quoted from Sonja Staar, Kunst, Widerstand und Lagerkultur, 36-37. 


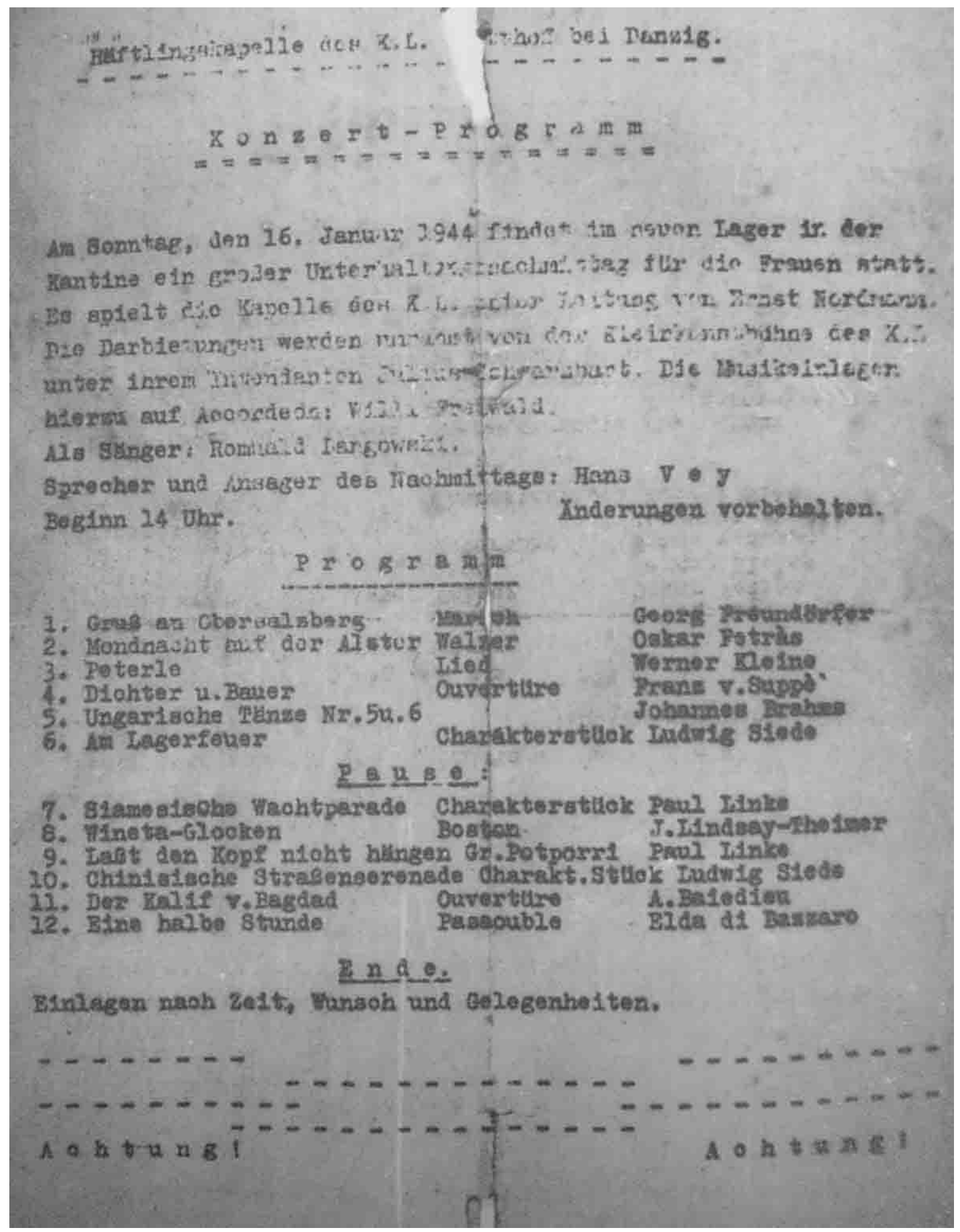

Figure 8. Program for an afternoon entertainment for female prisoners in the Stutthof concentration camp on January 16, 1944. Those taking part in this concert were: an announcer, an accordionist, a singer and the camp orchestra. Published in Guido Fackler, "Des Lagers Stimme" - Musik im KZ. Alltag und Häftlingskultur in den Konzentrationslagern 1933 bis 1936. Mit einer Darstellung der weiteren Entwicklung bis 1945 und einer Biblio-/ Mediographie, vol. 11 of DIZ-Schriften (Bremen, $2000)$, ill. 31 . 
Large-scale performances like these, often reaching hundreds of prisoners, were intended to counter a demoralizing tendency among the prisoners. Harry Naujoks, camp elder in Sachsenhausen explains: "The main point in our performances was to prevent the people from sinking into resignation, to give them new courage, to enable them to switch off for a few hours. This was vital, because hopelessness was one of the greatest dangers in the camp. When an individual was affected, it could lead to suicide, when whole groups were affected it could lead to disorganization and behavior that could bring down serious trouble with the SS" ${ }^{85}$ Although all camp inmates who were at liberty to move about the camp were free to attend camp performances, many, particularly in the final phase of the concentration camp system, were so weakened physically that they scarcely had the strength to take part: intellectual or artistic participation was beyond them because hunger dominated all.

We have already seen that the camp administration introduced concessions, but even after that there was no general permission for musical performances initiated by the prisoners, and these activities were repeatedly curtailed or for a time forbidden. Besides, there was a strictly regulated daily routine, with roll-calls, maintenance duties, exercises, and work duty, leaving little time for breaks or independent activities, so the only times when it was possible to play music were, generally speaking, the periods known as "leisure time". These periods encompassed just a few hours, for instance on Saturday afternoon or on Sundays, when there was generally no work, or after the evening roll-call. However, these few hours of "leisure time" were desperately needed for physical recuperation, and they were not infrequently interrupted by guards conducting searches, or inspections. Time was short, and daily life in the camps was characterized by fear and uncertainty. These circumstances, together with the extreme conditions in the camps, discouraged artistic activity. Engaging in music depended not least on the camp staff and the prisoner functionaries taking a favorable attitude. These various factors meant that independent musical activities invariably formed a high point in camp life, and they often remained the prerogative of those categories of prisoners high within the prisoner hierarchy, or those prisoners belonging to a "privileged" category. The bulk of the prisoners had to struggle to survive and had neither the strength nor the leisure to take part in musical activities, which were in any case relatively rare occurrences. During the last few months of the war, finally, conditions in the camps deteriorated further as the military situation worsened. When death marches got under way, musical performances generally ceased.

\section{Conclusions}

The preceding examples - and the list could easily be extended - demonstrate impressively that music played an integral part in the daily life of the Nazi concentration camps. Daily life in these camps was full of contradictions and gave rise to specific forms of behavior, rituals, normative and value systems which even today remain largely unstudied. When we analyze daily life in the camps from a cultural-historical perspective - taking musical activities as an example - we are confronted with a disturbing vista capable of shaking our conventional understanding of culture to

85 Harry Naujoks, Mein Leben im KZ Sachsenhausen 1936-1942, 297. 
its very foundations; we see deep into the multi-layered interior of the Nazi concentration camp as an institution of terror, inhumanity and destruction. Here, professional and amateur musicians, of different ages, genders and nationalities, played music on a regular basis; they did so on command, and on their own initiative, not infrequently on peril of their lives; they performed solo, in choirs, in chamber music groupings, in small ensembles, in jazz bands, in camp orchestras and in symphony orchestras. They played and even composed music of various kinds, from light music to classical music, from traditional folk songs to critical cabaret songs, from jazz tunes that were beyond the pale to bright and cheerful operetta melodies.

It is true that the guards, for their own evil ends, abused the prisoners who played music, and by forcing them to put on musical performances, deliberately promoted the "process of breaking the will, and degrading [the prisoners] as human beings". ${ }^{86}$ Nevertheless, the fact that music was performed in the camps forces us to realize that the prisoners should not be regarded as an undifferentiated "grey mass". We must instead attempt to grasp the concept of "the prisoner as a cultural being, ${ }^{" 77}$ confronted with the necessity of devising new cultural techniques and survival strategies under the conditions prevalent in the camps. To that extent it would be wrong to underestimate the effect of playing music independently as a method of coping practically and surviving culturally. The values and aesthetics inherent in music were a defense against the terror of the camps. However, it would be quite inappropriate to suggest that concentration camp prisoners played music and indulged in other artistic activities to support some kind of post hoc argument that the concentration camp system was not really all that bad. We must always bear in mind that whatever music was produced in the Nazi camps was produced in spite of constant hunger, mental and physical violence, impending disease and pestilence, an uncertain future, random acts of terror, and that the prisoners' lives were always in jeopardy. It is also important to remember that it was only a very small segment of prisoners who had the chance to engage with music at all, for the simple reason that their physical decline was not yet so far advanced that hunger dominated all their thoughts and all their deeds.

86 Eugen Kogon, Der SS-Staat, 99.

87 Christoph Daxelmüller, "Kulturelle Formen und Aktivitäten als Teil der Überlebens- und Vernichtungsstrategie in den Konzentrationslagern," in Christoph Dieckmann, Ulrich Herbert, and Karin Orth, eds., Die nationalsozialistischen Konzentrationslager. Entwicklung und Struktur, 2 vols. (Göttingen, 1998), vol. 2, 983-1005, quote on 993. 